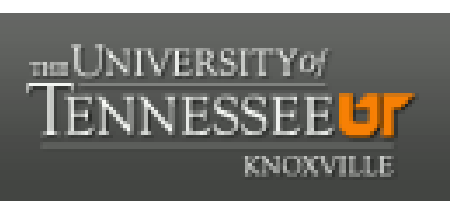

University of Tennessee, Knoxville

TRACE: Tennessee Research and Creative

Exchange

College of Law Faculty Scholarship

Law

January 2011

\title{
Antitrust Review of the AT\&T/T-Mobile Transaction
}

Maurice E. Stucke

University of Tennessee, mstucke@utk.edu

Allen Grunes

Follow this and additional works at: https://trace.tennessee.edu/utk_lawpubl

Part of the Antitrust and Trade Regulation Commons, Communications Law Commons, Consumer

Protection Law Commons, Evidence Commons, Law and Economics Commons, and the Law and

Psychology Commons

\section{Recommended Citation}

Stucke, Maurice E. and Grunes, Allen, "Antitrust Review of the AT\&T/T-Mobile Transaction" (2011). College of Law Faculty Scholarship.

https://trace.tennessee.edu/utk_lawpubl/58

This Article is brought to you for free and open access by the Law at TRACE: Tennessee Research and Creative Exchange. It has been accepted for inclusion in College of Law Faculty Scholarship by an authorized administrator of TRACE: Tennessee Research and Creative Exchange. For more information, please contact trace@utk.edu. 


\title{
Antitrust Review of the AT\&T/T- Mobile Transaction
}

\author{
Allen P. Grunes*
}

\section{Maurice E. Stucke**}

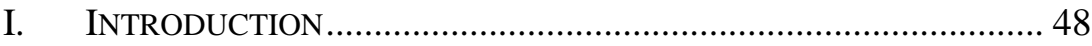

II. STANDARD FOR EVALUATING THE MERGER............................. 49

III. ThIS MERgER Is PRESUMPTIVELY ANTICOMPETITIVE ............... 51

A. AT\&T's Postmerger Market Share Would Exceed Forty

Percent.......................................................................... 52

B. Entry Barriers Are High ................................................... 54

C. The Incipiency Standard.................................................... 55

IV. The Merging Parties Have Not Overcome the

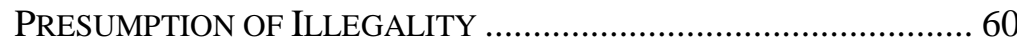

A. The Merging Parties Have Not Established That

Consumers Will Overall Benefit with Merger Specific

Efficiencies

* Shareholder, Brownstein Hyatt Farber Schreck, LLP.

** Associate Professor, University of Tennessee College of Law.

The Authors previously investigated mergers and other anticompetitive conduct while at the United States Department of Justice, Antitrust Division. Mr. Grunes's firm represents DISH Network, which opposes the AT\&T/T-Mobile merger. The views expressed in this Article are the Authors' own, and do not reflect those of any other person or entity. We would like to thank Peter C. Carstensen, Bernard M. Hollander, Daniel E. Lazaroff, Roger G. Noll, Barak Y. Orbach, and Christopher L. Sagers for their helpful comments. 

B. AT\&T and T-Mobile Have Not Rebutted the Presumption That the Significant Increase in Concentration in an Already Highly Concentrated Industry Will Increase the Likelihood of Tacit

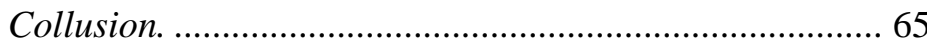

1. Handset Competition and Innovation ....................... 68

2. Text Messages.......................................................... 70

3. Parallel Accommodating Conduct ............................. 71

4. Unilateral Effects ........................................................ 72

5. Exclusionary Effects .................................................. 75

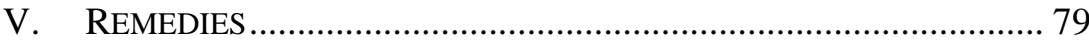

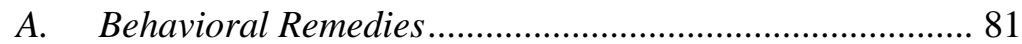

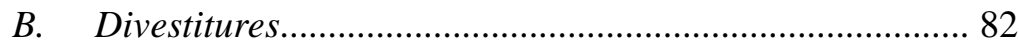

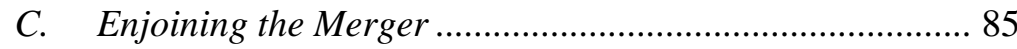

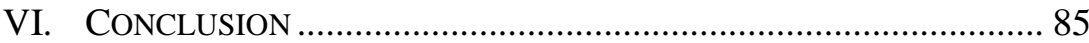

\section{INTRODUCTION}

Section 7 of the Clayton Act was intended to arrest the anticompetitive effects of market power in their incipiency. The core question is whether a merger may substantially lessen competition, and necessarily requires a prediction of the merger's impact on competition, present and future. The section can deal only with probabilities, not with certainties. And there is certainly no requirement that the anticompetitive power manifest itself in anticompetitive action before $\S$ 7 can be called into play. If the enforcement of $\S 7$ turned on the existence of actual anticompetitive practices, the congressional policy of thwarting such practices in their incipiency would be frustrated.

In this Article, we review the proposed \$39 billion merger between AT\&T and T-Mobile under federal merger law, under the United States Department of Justice (“DOJ”) and Federal Trade Commission (“FTC”)'s 2010 Horizontal Merger Guidelines, and with a focus on possible remedies. We find, under a rule of law approach, that the proposed acquisition is presumptively anticompetitive, and the merging parties in their public disclosures have failed to overcome this presumption. Next, we find that under the Merger Guidelines, there is reason to believe that the transaction may result in higher prices to consumers under several different plausible theories. Finally, we turn to the question of possible remedies. We conclude that there is a high likelihood that divestitures will not solve the competitive problems and make the case for enjoining the acquisition.

1. FTC v. Procter \& Gamble Co., 386 U.S. 568, 577 (1967) (citations omitted). 
On August 31, 2011, the United States brought an action to enjoin the merger. $^{2}$ The government's complaint was subsequently amended to include the claims of seven states and Puerto Rico as coplaintiffs. ${ }^{3}$ Two competitors also filed suit to enjoin the transaction and the defendants unsuccessfully moved to dismiss their complaints. ${ }^{4}$ The government's case is scheduled to go to trial on February 13, 2012.

\section{StANDARD FOR EVALUATING THE MERGER}

The starting point for any evaluation is the statute itself. Section 7 of the Clayton Act prohibits mergers and acquisitions when the effect of the transaction "may be substantially to lessen competition, or to tend to create a monopoly."6

Contemporary merger law is forward looking. Courts are called upon to make judgments about the likely effects of a merger that has not yet taken place. Uncertainty and errors of both overenforcement and underenforcement are inevitable. Some observers counsel for lenient merger review, as they believe the market will invariably correct any mistakes because new firms will enter and market power will quickly disappear. But the lessons from the financial crisis call into question these empirically suspect beliefs. ${ }^{7}$ Markets do not always self-correct. ${ }^{8}$ Most

2. Complaint, United States v. AT\&T, Inc. (2011), No. 11-01560, available at http://www.justice.gov/atr/cases/f274600/274613.htm. When we wrote and posted this article on SSRN, the DOJ was still investigating the merger.

3. Second Amended Complaint, United States v. AT\&T, Inc. (2011), No. 11-01560, http://www.justice.gov/atr/cases/f275700/275756.pdf [hereinafter Compl.].

4. Cecilia Kang, Judge Allows Sprint Suit Against AT\&T's Merger With T-Mobile, WAsH. Post (Nov. 3, 2011), http://www.washingtonpost.com/blogs/post-tech/post/ judgeallows-sprint-suit-against-atandts-merger-with-t-mobile/2011/11/03/gIQATxT5iM_blog.ht ml?wprss=post-tech. Although the complaints by Sprint and C Spire (formerly Cellular South) were not dismissed, they were significantly pared down by the court. Michael J. De La Merced, AT\&T Moves to Dismiss Lawsuits by Sprint and Cellular South, N.Y. TIMES DEALBoOK, Sept. 30, 2011, http://dealbook.nytimes.com /2011/09/30/att-moves-to-dismisslawsuits-by-sprint-and-cell-south/\#sprint.

5. Rachel King, AT\&T Antitrust Case Gets February Trial Date, CNET NEws (Sept. 22, 2011, 7:46 AM), http://news.cnet.com/8301-1035_3-20110079-94/at-t-antitrust-casegets-february-trial-date/.

6. 15 U.S.C. $\S 18$ (2006).

7. See Richard A. Posner, A Failure of Capitalism: The Crisis of '08 and the Descent Into Depression (2009); Paul Krugman, The Return of Depression ECONOMICS AND THE CRISIS OF 2008 (2009).

8. See, e.g., Kenneth M. Davidson, Reality Ignored: How Milton Friedman AND CHICAGO ECONOMICS UNDERMINED AMERICAN INSTITUTIONS AND ENDANGERED THE Global ECONOMY (2011); John CASSIDY, How MARKETS FAIL: THE LOGIC OF ECONOMIC Calamities 59 (2009); Justin Fox, The Myth of the Rational Market: A History of Risk, Reward, ANd Delusion on Wall Street (2009); George A. AKerlof \& Robert J. Shiller, Animal Spirits: How Human Psychology Drives the Economy, and Why It 
mergers do not yield significant efficiencies (which, if they did, would warrant a light touch approach to merger review). ${ }^{9}$

Instead, in the current era of Too-Big-and-Integral-to-Fail, we can see how Congress in the aftermath of World War II got it right. In amending the Clayton Act, Congress saw the dangers of concentrated economic and political power, and sought to arrest these threats in their incipiency. ${ }^{10}$ Thus, when evaluating mergers, the enforcers and the courts should respect Congress's desires and err, if anything, on the side of enforcement. Enforcement under the Clayton Act must also consider whether there is a trend toward concentration. "Long-term trends in HHI changes," the Fifth Circuit recently noted, "can be used to examine the structure of markets and are used to determine the effect of mergers on the market." ${ }^{11}$ Where the market trends show that the merging parties "have been the dominant players in the relevant markets and do not indicate any trend of reduced concentration ....," then a merger should be enjoined. ${ }^{12}$ An immediate danger of monopolization is not needed for a merger to be unlawful. ${ }^{13}$

The merger law, by its own language and Congress's intent, requires heightened scrutiny of mergers, especially those in already concentrated

MATtERS FOR Global CAPITALISM (2009); John Cassidy, Letter from Chicago: After the Blowup, NEw YORKER, Jan. 11, 2010, at 28, available at http://www.new yorker.com/reporting/2010/01/11/100111fa_fact_cassidy; Paul Krugman, How Did Economists Get It So Wrong?, N.Y. TiMES, Sept. 2, 2009, at 37, available at http:// www.nytimes.com/2009/09/06/magazine/06Economic-t.html?pagewanted=all (noting that more important than the economists' failure to predict was "the profession's blindness to the very possibility of catastrophic failures in a market economy”).

9. See, e.g., Amanda P. Reeves \& Maurice E. Stucke, Behavioral Antitrust, 86 IND. L.J. 1527, 1560-63 (2011); Spencer Weber Waller, Corporate Governance and Competition Policy, 18 Geo. MASON L. REv. 833, 873-79 (2011) (examining evidence from corporate finance that suggests entire categories of mergers are more likely to destroy, rather than enhance, shareholder value); Maurice E. Stucke, Behavioral Economists at the Gate: Antitrust in the Twenty-First Century, 38 Loy. U. CHI. L.J. 513, 573-75 (2007).

10. As the Court noted about the 1950 amendments to the Clayton Act, it was "apparent that a keystone in the erection of a barrier to what Congress saw was the rising tide of economic concentration, was its provision of authority for arresting mergers at a time when the trend to a lessening of competition in a line of commerce was still in its incipiency.” Brown Shoe Co. v. United States, 370 U.S. 294, 347 (1962). The Court noted, "[t]hat $\S 7$ of the Clayton Act was intended to reach incipient monopolies and trade restraints outside the scope of the Sherman Act was explicitly stated in the Senate Report on the original Act .... This theme was reiterated in congressional consideration of the amendments adopted in 1950, and found expression in the final House and Senate Reports on the measure.” Id. at 347 n.32 (citation omitted).

11. Chicago Bridge \& Iron Co. N.V. v. FTC, 534 F.3d 410, 432 n.12 (5th Cir. 2008).

12. Id.

13. Robert H. Lande, Resurrecting Incipiency: From Von's Grocery to Consumer Choice, 68 ANTITRUst L.J. 875 (2001). 
industries with entry barriers. ${ }^{14}$ Thus, the outcome for merger review should significantly differ than the outcome for evaluating antitrust restraints generally under the Sherman Act.

\section{This Merger Is PREsumptiVely ANTICOMPETITIVE}

Under well-established U.S. law, there is a strong presumption of illegality when the merging firms' market shares are significant in an industry with high entry barriers. As the Supreme Court said,

[A] merger which produces a firm controlling an undue percentage share of the relevant market, and results in a significant increase in the concentration of firms in that market is so inherently likely to lessen competition substantially that it must be enjoined in the absence of evidence clearly showing that the merger is not likely to have such anticompetitive effects." ${ }^{\circ}$

Consistent with the legislative intent of the Clayton Act, courts have regarded a transaction that would lead to further concentration in an already highly concentrated market as presumptively illegal under Section $7 .^{16}$ In United States v. Philadelphia National Bank, the Court held that a merger resulting in a single firm controlling thirty percent of a market trending toward concentration in which four firms controlled seventy percent of the sales was presumptively illegal. ${ }^{17}$ Unless the merging parties "meet their burden of rebutting this presumption, the merger must be enjoined." 18 That

14. See United States v. Phila. Nat’l Bank, 374 U.S. 321, 363-68 (1963).

15. Id.

16. See, e.g., United States v. Cont'l Can Co., 378 U.S. 441, 461 (1964); United States v. Aluminum Co. of America, 377 U.S. 271, 278, 280 (1964); FTC v. Swedish Match, 131 F. Supp. 2d 151 (D.D.C. 2000); FTC. v. Cardinal Health, Inc., 12 F. Supp. 2d 34, 53 (D.D.C. 1998) (finding that "[r]egardless of how one were to define the relevant drug wholesale market, whether it would include business to all or only some of its customers, the merged firms would control a significant share of all of the markets.”); United States v. Ivaco, Inc., 704 F. Supp. 1409, 1419 (W.D. Mich. 1989). Measures of concentration have changed over the years. For the past three decades, the antitrust agencies have used the "Herfindahl-Hirschman Index" or HHI. HHI is calculated by summing the squares of the market shares of all firms in the industry. In doing so, it gives greater weight to the market shares of larger firms than the shares of smaller firms, reflecting the fact that larger firms are generally more competitively significant. Prior measures of concentration merely added the market shares of the industry's largest companies. Thus, the "four firm concentration ratio" is the sum of the market shares of the four largest firms in an industry.

17. 374 U.S. at 364 ("Without attempting to specify the smallest market share which would still be considered to threaten undue concentration, we are clear that $30 \%$ presents that threat.”). Subsequent cases have lowered the presumption somewhat to even twentyfive percent or less. See United States v. Aluminum Co. of America, 377 U.S. 271, 275 (1964) (aggregate market share 29.1\%; acquired firm's market share 1.3\%; four-firm concentration ratio $76 \%)$.

18. R.C. Bigelow, Inc. v. Unilever N.V., 867 F.2d 102, 108 (2d Cir. 1989); see also Swedish Match, 131 F. Supp. 2d at 151; Cmty. Publishers, Inc. v. Donrey Corp., 892 F. Supp. 1146 (W.D. Ark. 1995), aff'd 139 F.3d 1180 (8th Cir. 1998). 
presumption applies to the AT\&T/T-Mobile merger in an already highly concentrated industry with high-entry barriers.

\section{A. AT\&T's Postmerger Market Share Would Exceed Forty Percent}

The candidate product market is the market for "mobile wireless telecommunications services."19 This was the market definition used in prior DOJ cases such as United States v. AT\&T Inc. ${ }^{20}$ and United States v. Verizon Communications Inc. ${ }^{21}$ In those cases, DOJ noted that there were no cost-effective alternatives to mobile wireless telecommunications services, and it is unlikely that a sufficient number of customers would switch away from mobile wireless telecommunications services to make a small but significant nontransitory price increase in those services unprofitable. $^{22}$

This candidate product market includes voice, text messaging, and data services. The data component of mobile wireless services has been rapidly growing in the past few years. There has been a high smartphone adoption and upgrade rate (close to fifty percent in 2009 according to the FCC's Fourteenth Mobile Wireless Competition Report). ${ }^{23}$ There has also been an expansion in the number of non-smartphone handsets that are subject to mandatory data plans. Data plans for mobile phones are typically sold as part of a bundle. At the end of the day, DOJ's product market candidate, which includes voice, messaging, and data, is defensible.

The candidate geographic markets include both local and national markets. ${ }^{24}$ Historically, viewed from the consumer perspective, geographic markets were local. ${ }^{25}$ This was because consumers purchasing mobile wireless telecommunications services chose among the providers that offered services where they lived, worked, and traveled on a regular

19. This is the product market alleged by the United States in its complaint. See Compl. at 7.

20. Complaint at 1, United States v. AT\&T Inc., 541 F. Supp. 2d 2 (D.D.C. 2008) (No. 1:07-cv-01952), http://www.justice.gov/atr/cases/f227300/227306.pdf [hereinafter AT\&T Compl.].

21. Complaint at 1, United States v. Verizon Comm. Inc., 607 F. Supp. 2d 1 (D.D.C. 2009) (No. 1:08-cv-00993), http://www.justice.gov/atr/cases/f233900/233928.pdf [hereinafter Verizon Compl.].

22. See, e.g., AT\&T Compl., supra note 20, at 2; Verizon Compl., supra note 21, at 2.

23. Implementation of Section 6002(b) of the Omnibus Budget Reconciliation Act of 1993, Fourteenth Report, 25 F.C.C.R. 11407, para. 137, Chart 6 (WTB 2010), http://hraunfoss.fcc.gov/edocs_public/attachmatch/FCC-10-81A1.pdf [hereinafter 14th Mobile Wireless Competition Report].

24. Compl., supra note 3, at 9-12 (evaluating competition both at local level and nationwide competition across local markets).

25. Id. at 10 . 
basis. ${ }^{26}$ Historically, providers offered different promotions, discounts, calling plans, and equipment subsidies in different geographic areas, varying the price for customers by geographic area. ${ }^{27}$

By the end of 2008, however, there were four facilities-based mobile wireless service providers that industry observers typically described as "nationwide": AT\&T, Sprint Nextel, T-Mobile, and Verizon Wireless. ${ }^{28}$ In 2008, all the nationwide operators launched unlimited national flat-rate calling plans. ${ }^{29}$ Consumers increasingly have shifted away from restricted plans that included separate roaming charges and into these unlimited service options, and the focus of price competition has shifted accordingly. ${ }^{30}$ It now appears that pricing is for the most part set nationally by the four nationwide carriers, and regional and local competitors do not act as significant constraints on national pricing.

Indeed, in its FCC public interest statements in both the Dobson ${ }^{31}$ and Centennial $^{32}$ acquisitions, AT\&T acknowledged that the geographic market is national precisely for these reasons. As AT\&T wrote in its Centennial statement, supported by a declaration from its Chief Marketing Officer, "[i]n the mainland U.S., AT\&T establishes its rate plans and pricing on a national basis, without reference to market structure at the [Cellular Market Area] level.",33 AT\&T's statement continues: "One of AT\&T's objectives is to develop its rate plans, features and prices in response to competitive conditions and offerings at the national levels [sic] — primarily the plans offered by the other national carriers."34

Although pricing by the four nationwide operators appears to be largely national, there may be promotions or discounts (e.g., handset discounts) that occur on a local basis. At trial, the court will likely consider

26. Id. at 9 .

27. See, e.g., AT\&T Compl., supra note 20; Compl., supra note 3, at 9.

28. 14th Mobile Wireless Competition Report, supra note 23, at para. 27.

29. Id. at para. 88 .

30. Id. at para. 90 .

31. AT\&T, MERger of AT\&T InC. AND DOBSON COMMUNICATIONS CoRPORATION, Description of Transaction, Public Interest Showing and Related Demonstrations (July 13, 2007) (filed with the FCC), available at https://wireless2.fcc.gov/UlsEntry /attachments/attachmentViewRD.jsp?applType=search\&fileKey=688206512\&attachmentK ey $=18223538 \&$ attachmentInd=applAttach.

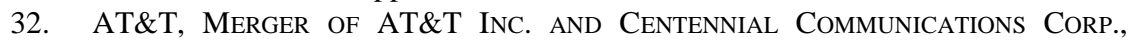
Description of Transaction, Public Interest Showing and Related Demonstrations (Nov. 21, 2008) (filed with the FCC), available at https://wireless2.fcc.gov/UlsEntry/ attachments/attachmentViewRD.jsp;ATTACHMENTS=1N6VJL5K37mPzN1G7L2XKBP7 mC5jC50m96ttqVlHZr3GL1cyJSgx!-659400886!-849295342?applType=search\&fileKey $=843683410 \&$ attachmentKey=18355849\&attachmentInd=applAttach.

33. Id. at 28.

34. Id.at 28-29. 
how much of these promotions and discounts are driven by competition. The court will also consider how big a factor the local promotions and discounts play in the overall pricing picture of AT\&T, T-Mobile, Verizon, and Sprint. For example, if a two-year wireless plan costs $\$ 1200$ per year, but there is a fifty dollar discount available in some cities on a new phone, that would amount to about a two percent discount over two years and would probably be small enough not to undercut the overall national pricing picture.

Viewed from the standpoint of business customers, where travel capabilities are important and contracts are negotiated, the same conclusion appears likely: the geographic market is national. Similarly, viewed from the standpoint of suppliers (e.g., handset manufacturers), the geographic market is undoubtedly national. It is interesting to note that, according to an AT\&T executive, Apple apparently approached Verizon, Sprint, AT\&T, and T-Mobile about the original iPhone. ${ }^{35}$

Consequently, under this proposed market definition, the merging parties will have a significant market share. As Senator Herbert Kohl observed at the recent hearings on this merger, "The proposed merger between AT\&T and T-Mobile will bring together two of the four remaining national cell phone carriers to create the nation's largest cell phone network, with an estimated $43 \%$ market share. Should this deal be approved, AT\&T and Verizon will control close to $80 \%$ of the national cell phone market." ${ }^{36}$ Under the Merger Guidelines, the merger would significantly increase concentration in the already concentrated national market and in ninety-seven of the top one hundred local markets. ${ }^{37}$

\section{B. Entry Barriers Are High}

Entry into the market of mobile wireless telecommunications services requires either (a) building out a network and obtaining spectrum rights, a slow process with high capital costs, or (b) piggy-backing on an existing provider, which is quicker but potentially more constrained (since network access, contract terms, and growth are all subject to a competitor's willingness to contract). ${ }^{38}$

35. See Lafayette Policy Studies Program, Jacoby Lecture, YouTubE, 17:50 (April 11, 2011), http://www.youtube.com/user/lafayettepolicystds\#p/u/0/j6Pqp40rigo.

36. Press Release, Senator Herb Kohl, Statement of U.S. Senator Herb Kohl on the AT\&T/T-Mobile Merger (May, 11, 2011), http://kohl.senate.gov/newsroom/pressrelease .cfm?customel_dataPageID_1464=4452.

37. Compl., supra note 3, at 12-14.

38. See 14th Mobile Wireless Competition Report, supra note 23, at paras. 60 (facilities based entry), 36, n.91 (mobile virtual network operators); Compl. at 21 ("To replace the competition that would be lost from AT\&T's elimination of T-Mobile as an 
The inputs necessary to enter include spectrum, towers, network equipment, and backhaul facilities. We doubt there can be a serious claim that entry is easy. Moreover, as Tim Wu discusses in his book, The Master Switch, there is apparently reason to be skeptical of AT\&T's willingness to grant competitors reasonable access to its network. ${ }^{39}$

\section{The Incipiency Standard}

For the past thirty years or so, DOJ has looked at deals one at a time, and has not made use of Section 7's "incipiency" standard, ${ }^{40}$ which requires the antitrust enforcers to nip concentration in the bud. ${ }^{41}$ Nor has DOJ examined trends toward concentration, and the likely impact that such concentration would have on the overall competitiveness of an industry. The 2010 revisions to the Horizontal Merger Guidelines have changed this approach. The Merger Guidelines now refer to the Congressional intent "that merger enforcement should interdict competitive problems in their incipiency and that certainty about anticompetitive effect is seldom possible and not required for a merger to be illegal."42

Indeed, ignoring the Clayton Act's incipiency standard raises significant rule-of-law concerns. Congress, in passing Section 7 and in amending it with the Celler-Kefauver Anti-Merger Amendments, "was concerned with arresting concentration in the American economy, whatever its cause, in its incipiency." 43 To halt the "'rising tide' of concentration in American business," Congress decided “"to clamp down with vigor on

independent competitor, moreover, a new entrant would need to have nationwide spectrum, a national network, scale economies that arise from having tens of millions of customers, and a strong brand, as well as other valued characteristics.”).

39. Tim Wu, The Master Switch: The Rise and Fall of Information Empires 245-49 (2011).

40. A search of the DOJ Antitrust Division website produced a few court cases where the United States mentioned the incipiency standard including some recent instances. See Plaintiffs' Proposed Conclusions of Law, United States v. Oracle Corp., 331 F. Supp. 2d. 1098 (N.D. Cal. 2004) (No. C 04-0807 VRW), www.justice.gov/atr/cases/f204500/204558

.pdf; Plaintiff United States of America's Motion to Strike Defendants' Efficiencies Defense, United States v. Northwest Airlines Corp., No. 98-74611 (E.D. Mich. 2000), available at http://www.justice.gov/atr/cases/f4500/4542.htm; Memorandum of United States in Support of Motion for a Temporary Restraining Order and a Preliminary Injunction, United States v. Franklin Electric Co., 130 F. Supp. 2d 1025 (W.D. Wisc. 2000), www.justice.gov/atr/cases/f4800/4883.pdf.

41. United States v. E. I. du Pont de Nemours \& Co., 353 U.S. 586, 589, 593 (1957).

42. U.S. Dep’t of Justice \& FTC, Horizontal Merger Guidelines § 1 (2010), available at http://www.justice.gov/atr/public/guidelines/hmg-2010.html [hereinafter 2010 Horizontal Merger Guidelines].

43. United States v. Pabst Brewing Co., 384 U.S. 546, 552 (1966). 
mergers." "44 Congress's premise was that mergers tend to accelerate concentration in an industry:

The use of these words ["may be"] means that the bill, if enacted, would not apply to the mere possibility but only to the reasonable probability of the prescribed [sic] effect $* * *$. The words 'may be' have been in section 7 of the Clayton Act since 1914. The concept of reasonable probability conveyed by these words is a necessary element in any statute which seeks to arrest restraints of trade in their incipiency and before they develop into full-fledged restraints violative of the Sherman Act. A requirement of certainty and actuality of injury to competition is incompatible with any effort to supplement the Sherman Act by reaching incipient restraints.

With the rise of the Chicago School in the late 1970s, it became fashionable among antitrust economists and lawyers to dismiss the incipiency standard as outdated. Before the financial crisis, the conventional wisdom was that antitrust enforcers and courts could (and should) use concentration only as a screen: the antitrust agencies would challenge only those few mergers that, under the prevailing economic thinking, would demonstrably lead to a postmerger price increase. ${ }^{46}$ It came to the point where the agencies seemed obligated not only to prove that a merger would cause prices to rise postmerger, but also explain the chain of events that would lead to the postmerger price increase (either unilateral or coordinated effects) and the likely magnitude of the price increase. $^{47}$

It is difficult to imagine how a DOJ or FTC attorney, even one with an MBA, could be expected to meet this burden. For some industries, anticompetitive effects may be relatively easy to predict; but in other industries, making such predictions is a fool's errand. The merging parties' documents may be useful, but repeat players before the agencies can be expected to know what to put into, and what to leave out of, their planning documents. Indeed, any well-counseled firm that plans to continue to grow through mergers knows this lesson very well.

The revised Merger Guidelines now state, in discussing coordinated effects, that this level of predictive causation is not called for: "Pursuant to

44. Id. at 552 (quoting United States v. Von's Grocery Co., 384 U.S. 270, 276 (1966)).

45. Brown Shoe Co. v. United States, 370 U.S. 294, 323 n.39 (1962) (quoting Senator Reed from the Congressional Record).

46. Lawrence M. Frankel, The Flawed Institutional Design of U.S. Merger Review: Stacking the Deck Against Enforcement, 2008 UTAH L. REV. 159, 159 (2008).

47. See, e.g., United States v. Oracle Corp., 331 F. Supp. 2d 1098, 1165 (N.D. Cal. 2004) (misconstruing the Clayton Act's incipiency standard, the trial court held that "[w]ithout the benefit of presumptions, the burden remains upon plaintiffs to come forward with evidence of actual anticompetitive effects.”). 
the Clayton Act's incipiency standard, the Agencies may challenge mergers that in their judgment pose a real danger of harm through coordinated effects, even without specific evidence showing precisely how the coordination likely would take place."48

This recognition does much to bring the agencies back into line with the law. Congress and the courts have recognized that some economists and lawyers might believe that the disappearance of smaller competitors and greater industry concentration are bound to occur whether mergers are prohibited or not. ${ }^{49}$ But this is not their decision to make. As the Supreme Court noted, "it is not for the courts to review the policy decision of Congress that mergers which may substantially lessen competition are forbidden, which in effect the courts would be doing should they now require proof of the congressional premise that mergers are a major cause of concentration. $" 50$ Nor should it be left to the whim of the particular court or agency official to decide whether a trend toward concentration in an industry, whatever its causes, is a relevant factor in deciding whether the merger violates the Clayton Act. Congress determined that the trend toward concentration is a highly relevant factor.

Under the incipiency standard, the AT\&T/T-Mobile merger is highly problematic. The typical local market for mobile wireless services is already highly concentrated and the trend prior to this acquisition has been toward greater concentration. ${ }^{51}$ The FCC states that concentration has increased thirty-two percent since 2003 and six and a half percent in the most recent year for which data is available. ${ }^{52}$ The weighted average HHI (weighted by "Economic Area" population which is an aggregation of counties including the "node" and the surrounding areas economically related to the node) was 2848 in 2008, an increase from 2674 in 2007..$^{53}$ The weighted average HHI has increased by nearly 700 since the FCC first calculated this metric in $2003 .{ }^{54}$ On a national basis, the trend toward concentration is equally apparent.

To see the impact of the incipiency standard on merger review, take as an example Aluminum Company of America's acquisition of a small

48. 2010 Horizontal Merger Guidelines, supra note 42, § 7.1.

49. United States v. Pabst Brewing Co., 384 U.S. 546, 552 (1966) (noting how "[m]any believe . . . that the disappearance of small businesses with a correlative concentration of business in the hands of a few is bound to occur whether mergers are prohibited or not.”).

50. Id.

51. Compl., supra note 3, at paras. 22-23.

52. See 14th Mobile Wireless Competition Report, supra note 23, at 6.

53. See id. at 15; as to how HHIs are calculated, see supra note 16.

54. See 14th Mobile Wireless Competition Report, supra note 23, at 15. 
competitor, Rome Cable Corporation. ${ }^{55}$ The Court noted that the acquisition gave the dominant firm Alcoa only 1.3\% additional control of the aluminum conductor line market. ${ }^{56}$ Indeed, although Rome was an aggressive competitor, it was unlikely that Alcoa could significantly increase its market power. ${ }^{57}$ If the agencies or courts ignored the incipiency standard and required proof of the specific anticompetitive effects postmerger, then the dominant firms could acquire their smaller rivals one at a time, notwithstanding the federal antitrust law. It is unlikely that DOJ could prove why and how prices would increase as a result of this merger, or the magnitude of the price increase. But this standard, besides being unrealistic, contravenes the legislative intent. In the Alcoa-Rome Cable merger, the Court did not ramble through the wilds of economic theory. Instead, the Court turned to the statute and its legislative history: the Committee Reports on Section 7 show, with respect to the Celler-Kefauver Amendments in 1950, that "the objective was to prevent accretions of power which 'are individually so minute as to make it difficult to use the Sherman Act test against them.",58 Thus, under the incipiency standard, "[i]t would seem that the situation in the aluminum industry may be oligopolistic. As that condition develops, the greater is the likelihood that parallel policies of mutual advantage, not competition, will emerge. That tendency may well be thwarted by the presence of small but significant competitors." ${ }^{59}$ While, for some, Alcoa may be an extreme example, it illustrates a valid point. Incipiency is not a novel concept for the courts. ${ }^{60}$

55. United States v. Aluminum Co. of Am, 377 U.S. 271, 272-73 (1964).

56. Id. at $273-74$ (finding that Rome in the year prior to the merger produced " $0.3 \%$ of total industry production of bare aluminum conductor, $4.7 \%$ of insulated aluminum conductor, and $1.3 \%$ of the broader aluminum conductor line.”). That same year, Alcoa "produced $32.5 \%$ of the bare aluminum conductor, $11.6 \%$ of insulated aluminum conductor, and $27.8 \%$ of aluminum conductor." Id. at 274; see also id. at 280 ("The acquisition of Rome added, it is said, only $1.3 \%$ to Alcoa's control of the aluminum conductor market.”).

57. The Court was clearly concerned about the trend toward concentration. It noted how "[i]t would seem that the situation in the aluminum industry may be oligopolistic." Id. at 280. The Court was concerned of the "likelihood that parallel policies of mutual advantage, not competition, will emerge" in this industry. Id. This trend toward oligopoly, observed the Court "may well be thwarted by the presence of small but significant competitors." Id. (emphasis added). Moreover, the evidentiary record showed that Rome "was an aggressive competitor." Id. at 281.

58. Id. at 280 (citations omitted).

59. Id.

60. Section 8 of the Clayton Act, which prohibits interlocking directorates, also employs an incipiency standard. Courts have long recognized that the purpose behind Section 8 was "to nip in the bud incipient violations of the antitrust laws by removing the opportunity or temptation to such violations through interlocking directorates." United States v. Sears, Roebuck \& Co., 111 F. Supp. 614, 616 (S.D.N.Y. 1953). 
Indeed, the incipiency standard places antitrust on surer footing under rule of law principles, than having the agencies or generalist courts trying to predict what in many industries is unpredictable. As the Court has long recognized, the relevant economic data are "both complex and elusive."61 If the legality of a merger rises and falls on the ability of the agencies to prove the nature and magnitude of the postmerger anticompetitive effects, then business executives will not know which mergers would likely be blocked. Such a vague, fact-specific rule of reason analysis would benefit antitrust lawyers and economists (and data production teams to comply with the onerous Second Request for "additional information and documentary material relevant to the proposed acquisition.”). ${ }^{62}$ But merger law is now nothing more than haphazard merger predictions, which raises significant rule-of-law concerns, "[a]nd unless businessmen can assess the legal consequences of a merger with some confidence, sound business planning is retarded."63 Under the current incipiency standard and presumption, the merging parties (and antitrust agencies to the extent they permit such mergers to go through) must produce evidence clearly showing that the merger is unlikely to have anticompetitive effects. ${ }^{64}$ The evidence should be so clear that citizens and Congress are confident that the risks inherent in the transaction are insignificant, and the procompetitive benefits are significant. ${ }^{65}$ If the merging parties (and antitrust agencies) fail to overcome this presumption, then there is little confidence that the law is being enforced as it should be.

The Philadelphia National Bank presumption is not only consistent with congressional intent (in preventing a too broad of an economic investigation), but it provides firms, especially those in concentrated industries, some guidance as to whether they or their competitors can merge (without running afoul of the Clayton Act). Indeed, it can re-channel

61. United States v. Phila. Nat’l Bank, 374 U.S. 321, 362 (1963).

62. 15 U.S.C. $\S 18 a(e)(1)(A)(2000)$.

63. Phila. Nat'l Bank, 374 U.S. at 362.

64. See, e.g., Christian Schmidt Brewing Co. v. G. Heileman Brewing Co., Inc., 600 F. Supp. 1326, 1330 (E.D. Mich. 1985) ("In evaluating this evidence, [courts] must keep in mind the Supreme Court's instruction that a merger which produces a firm with an undue market share and significantly increases concentration in the industry 'is so inherently likely to lessen competition substantially that it must be enjoined in the absence of evidence clearly showing that the merger is not likely to have such anti-competitive effects."”) (quoting United States v. Philadelphia National Bank, 374 U.S. 321, 363 (emphasis added by district court), aff'd, 753 F.2d 1354 (6th Cir. 1985).

65. See, e.g., Tasty Baking Co. v. Ralston Purina, Inc., 653 F. Supp. 1250, 1264 (E.D. Pa. 1987) (defendants can overcome presumption with significant evidence "that the market-share statistics g[i]ve an inaccurate account of the acquisition['s] probable effects on competition”) (quoting United States v. Citizens \& Southern National Bank, 422 U.S. 86, $120(1975))$. 
some of the wasted costs in lobbying policymakers ${ }^{66}$ (and fees to investment bankers) that arise from merger waves. Knowing that the merger is presumptively illegal, and knowing that the evidentiary showing to overcome this presumption is significant, many large firms in concentrated industries recognize that neither they nor their significant competitors can further increase industry concentration with another merger. This can increase their incentives to grow organically through superior internal efficiencies, technologies, services, and offerings.

Consequently, under well-established U.S. law, there is a strong presumption of illegality when the merging firm's market share exceeds thirty percent in a highly concentrated industry with high entry barriers. As we examine below, the merging parties (through their public disclosures at least) have not overcome this strong presumption of illegality.

\section{The Merging Parties Have Not Overcome the PRESUMPTION OF ILLEGALITY}

\section{A. The Merging Parties Have Not Established That Consumers Will Overall Benefit with Merger Specific Efficiencies}

"Although the Supreme Court has not sanctioned the use of the efficiencies defense in a section 7 merger case, the trend among lower courts is to recognize the defense." $" 67$ Based on the publicly available information, it is unlikely that AT\&T will overcome this presumption of anti-competitive harm with an efficiencies defense. Instead we find: (i) many of the efficiencies that AT\&T claims are not "merger specific" and thus not "cognizable” under the agencies' Horizontal Merger Guidelines, and (ii) to obtain efficiencies in one part of the merged company (i.e., on the AT\&T side), the company will need to cause harm somewhere else (i.e., on the T-Mobile side).

The merger does not really expand wireless coverage area for customers. Apparently the coverage profiles of AT\&T and T-Mobile are fairly similar, so it is unlikely that combining the companies will create significant improvements in coverage area. ${ }^{68}$ The latest buzz is $4 \mathrm{G}$ wireless technologies, which offer theoretical download speeds of $100 \mathrm{Mbps}$, with the technology based on orthogonal frequency-division multiplexing

66. See Maurice E. Stucke, Crony Capitalism and Antitrust, CPI ANTITRUST CHRONICLE (forthcoming 2011) (discussing AT\&T and T-Mobile's lobbying efforts to gain approval of their merger) (abstract available at http://ssrn.com/abstract=1942045).

67. FTC v. H.J. Heinz Co., 246 F.3d 708, 720 (D.C. Cir. 2001) (citations omitted).

68. See Jessica Dolcourt, AT\&T and T-Mobile: By the Numbers, CNET (Mar. 20, 2011), http://www.cnet.com/8301-17918_1-20045216-85.html. 
(“OFDM"). ${ }^{69}$ To the extent that the merger allegedly gives T-Mobile a "clear path" to 4G services, this is not merger-specific. Just giving customers of one of the merging parties access to something that the other party offers is not a merger-specific efficiency. Customers who value that feature could switch to the other provider absent the merger. Moreover, if there is evidence that T-Mobile was independently working on the equivalent of $4 \mathrm{G}$ (and there is here), then this undercuts the efficiency defense. The argument that T-Mobile has "no clear path" towards 4G only begs the question: in a competitive environment, under the rigors of competition, T-Mobile needs to find such a path. ${ }^{70}$ The lack of a "clear path" is an incentive to innovate and compete harder. The asserted benefit of the merger, from T-Mobile's standpoint, is that AT\&T can migrate TMobile users to its network. This is not a true efficiency because the choice is already part of a price-quality tradeoff for consumers.

To the extent that the merger gives AT\&T needed spectrum, there are less anticompetitive alternatives for AT\&T to get more spectrum. One argument in favor of the merger is that AT\&T is running out of spectrum as data-hungry users are using what AT\&T currently offers. ${ }^{71}$ But there are other ways for AT\&T to get needed spectrum that would not harm competition. The irony should not be lost on anyone that the video and music needs of a segment of AT\&T customers appear to be the driving force of this merger. In order to satisfy those needs, AT\&T is proposing to restructure the industry.

One efficiency that may be associated with the acquisition is that it will give the merged firm more spectrum options, which will allow it to deploy spectrum most efficiently. Not all spectrum is created equally, and thus there may be benefits to both T-Mobile and AT\&T if they are able to redeploy spectrum. As the FCC noted:

[S]pectrum resources in different frequency bands have distinguishing features that can make some frequency bands more valuable or better suited for particular purposes. For instance, given the superior propagation characteristics of spectrum under $1 \mathrm{GHz}$, particularly for providing coverage in rural areas and for penetrating buildings,

69. Marguerite Reardon, Which 4G Service Is Right For You? (FAQ), CNET NEws (Dec. 3, 2010, 4:00 AM), http://news.cnet.com/8301-30686_3-20024511-266.html\# ixzz1Muvdpsuq.

70. References to T-Mobile's alleged lack of a “clear path” to Long Term Evolution (“LTE”) appear repeatedly in AT\&T's public interest statement. See AT\&T, ACQUISITION of T-Mobile USA, Inc. By AT\&T InC.: Description of Transaction, Public InTEREst Showing ANd Related Demonstrations 1, 5, 13, 19, 30-32, 41, 43, 71, 102 (Apr. 21, 2011) [hereinafter AT\&T SuBMISSION] (filed with the FCC), https://prodnet.www.neca. org/publicationsdocs/wwpdf/42111att.pdf.

71. See AT\&T’s Answer, United States v. AT\&T, Inc. (2011), No. 11-01560. 
providers whose spectrum assets include a greater amount of spectrum below $1 \mathrm{GHz}$ spectrum may possess certain competitive advantages for providing robust coverage when compared to licensees whose portfolio is exclusively or primarily comprised of higher frequency spectrum. As discussed above, holding a mix of frequency ranges may be optimal from the perspective of providing the greatest service quality at low cost.

The spectrum holdings in the industry as of 2009 were as follows: ${ }^{72}$

Percentage Spectrum Holdings, Measured on a MHz POPs Basis by Provider, by Frequency Band*

(Providers Listed by Number of Subscribers as of 2Q 2009)

\begin{tabular}{|l|l|l|l|l|l|l|l|}
\hline \multicolumn{1}{|c|}{ Licensee } & \multicolumn{1}{|c|}{$\begin{array}{c}\mathbf{7 0 0} \\
\mathbf{M H z}\end{array}$} & $\begin{array}{c}\text { Cellular } \\
\mathbf{( 8 5 0} \\
\mathbf{M H z}\end{array}$ & $\begin{array}{c}\text { SMR } \\
\mathbf{( 8 0 0 / 9 0 0} \\
\mathbf{M H z})\end{array}$ & $\begin{array}{c}\text { PCS } \\
\mathbf{( 1 . 9} \mathbf{G H z})\end{array}$ & $\begin{array}{c}\text { AWS } \\
\mathbf{( 1 . 7 / 2 . 1} \\
\mathbf{G H z})\end{array}$ & $\begin{array}{c}\text { BRS } \\
\mathbf{( 2 . 5} \mathbf{G H z})\end{array}$ & $\begin{array}{c}\text { EBS } \\
\text { Leases } \\
\mathbf{( 2 . 5} \mathbf{~ G H z})\end{array}$ \\
\hline $\begin{array}{l}\text { Verizon } \\
\text { Wireless }\end{array}$ & $42.7 \%$ & $48.5 \%$ & $0.0 \%$ & $15.4 \%$ & $15.0 \%$ & $0.0 \%$ & $0.0 \%$ \\
\hline AT\&T & $24.3 \%$ & $42.3 \%$ & $0.0 \%$ & $25.9 \%$ & $11.2 \%$ & $0.0 \%$ & $0.0 \%$ \\
\hline Sprint Nextel & $0.0 \%$ & $0.0 \%$ & $93.0 \% *$ & $26.8 \%$ & $0.0 \%$ & $0.0 \%$ & $0.0 \%$ \\
\hline T-Mobile & $0.0 \%$ & $0.0 \% * *$ & $0.0 \%$ & $19.7 \%$ & $27.5 \%$ & $0.0 \%$ & $0.0 \%$ \\
\hline MetroPCS & $0.5 \%$ & $0.0 \%$ & $0.0 \%$ & $2.6 \%$ & $5.9 \%$ & $0.0 \%$ & $0.0 \%$ \\
\hline US Cellular & $2.7 \%$ & $4.3 \%$ & $0.0 \%$ & $1.8 \%$ & $2.0 \%$ & $0.0 \%$ & $0.0 \%$ \\
\hline Leap & $0.0 \%$ & $0.0 \%$ & $0.0 \%$ & $2.3 \%$ & $8.8 \%$ & $0.0 \%$ & $0.0 \%$ \\
\hline Other & $29.8 \%$ & $4.9 \%$ & $7.0 \% *$ & $5.5 \%$ & $29.6 \%$ & $13.7 \% *$ & $38.0 \% *$ \\
\hline Clearwire & $0.0 \%$ & $0.0 \%$ & $0.0 \%$ & $0.0 \%$ & $0.0 \%$ & $86.3 \% *$ & $62.0 \% *$ \\
\hline Grand Total & $100.0 \%$ & $100.0 \%$ & $100.0 \%$ & $100.0 \%$ & $100.0 \%$ & $100.0 \%$ & $100.0 \%$ \\
\hline
\end{tabular}

* These are estimates based on the available data.

** T-Mobile holds a very small amount of Cellular spectrum.

T-Mobile's spectrum holdings are almost entirely above $1 \mathrm{GHz}$. This suggests, at a minimum, that AT\&T's commitment to build out its network in rural areas is largely independent of anything it is gaining in the acquisition. T-Mobile's spectrum holdings are not well-suited for rural build-outs. Rather, this promise seems to be politically driven and aimed at senators and representatives from largely rural states. As a cost of getting support for the transaction, AT\&T is willing to spend more on rural markets. Merger critics point out that Verizon already plans to cover more than ninety percent of the U.S. population with 4G LTE service by $2013{ }^{73}$

72. 14th Mobile Wireless Competition Report, supra note 23, at 148, Table 25.

73. See Petition to Deny of Public Knowledge and Future of Music Coalition at 5960, Applications of AT\&T Inc. and Deutsche Telekom AG (No. 11-65) (2011), http://www. publicknowledge.org/files/docs/pk_fmc-att_tmo-petition_to_deny.pdf. 
and competition, rather than promises, is what is likely to cause AT\&T to increase its own coverage. ${ }^{74}$

On the other hand, at least parts of T-Mobile's spectrum, licenses, and probably towers are valuable in the urban areas where AT\&T is apparently having network difficulties. The likely argument is that both firms will benefit by redeployment of assets. Of course, this same argument can be used whenever firms have to compete for scarce inputs, and no firm wins all the auctions. Critics have contended that AT\&T could take the money it is spending on the acquisition and spend it on network improvements, and that would be a more procompetitive outcome.

AT\&T's efficiency argument essentially comes down to this: what is good for AT\&T is good for the United States. It equates its increase in dominance, and its elimination of a significant competitor, as somehow proconsumer, proinnovation and proinvestment. AT\&T's lead filing with the FCC contains dire predictions if its merger is blocked. AT\&T predicts that consumers will confront "lower output, worse quality, and higher prices. ${ }^{, 75}$ It alleges that preventing its acquisition of T-Mobile would risk "degrading service for millions of American consumers, undermining the virtuous cycle of mobile broadband innovation, and imperiling U.S. technological leadership."76 It warns that prohibiting its merger will cause AT\&T to have capacity problems, which "could have ripple effects throughout the broadband ecosystem." "77 It also warns that absent the merger, consumers would face even "more dropped and blocked calls, slower speeds, and access to fewer and less advanced applications."78

It is entirely rational for AT\&T to equate its corporate interests with America's interest. Indeed, this attitude suggests that America is already too dependent upon AT\&T, and, thus, must allow the company to grow even bigger. But this is not the mindset of consumers or society. Rather what is good for America is good for AT\&T. And what is good for America generally means more, rather than less, competition. If spectrum is, as AT\&T argues, a scarce resource, then all competitors are confronted with this scarcity. While AT\&T argues that dominant firms should grow bigger by acquiring their competitors' spectrum, that is not necessarily in our country's best interest. Instead, the fundamental belief is that

74. See The Effect of AT\&T's Acquisition of T-Mobile is Likely to Substantially Lessen Competition, AMERICAN ANTITRUST InSTITUTE, 3 (August 2011), http://www.antitrust institute.org/ antitrust/sites/default/files/White\%20paper.pdf.

75. AT\&T SUBMISSION, supra note 70, at 71 .

76. Id. at 14 .

77. Id. at 62 .

78. Id. at 6 . 
competition forces companies to better allocate scarce resources. ${ }^{79}$ AT\&T complains that, unlike its competitors, it supports multiple generations of technology, and this "severely constrains its flexibility to use its spectrum with optimal efficiency." 80 AT\&T claims that migrating its customers to new handsets takes too much time. ${ }^{81}$ But the remedy for AT\&T's dilemma is not to acquire its competitor to address its own inefficiencies. Instead, AT\&T must do better, and find better ways to innovate to serve its customers. In a competitive environment, if AT\&T falls behind, it risks losing customers to more nimble competitors. In a less competitive environment, these customers have correspondingly fewer options.

There is another reason to be wary of AT\&T's belief that what serves its corporate interests benefits Americans. Notwithstanding its claims of being an innovation pioneer, AT\&T was "the lowest-scoring cell-phone carrier in the U.S., according to a satisfaction survey of 58,000 ConsumerReports.org readers., ${ }^{, 82}$ Of all the carriers rated, AT\&T was the only one to drop significantly in overall satisfaction. While AT\&T points out that it introduced Apple's iPhone, ${ }^{83}$ Consumer Reports recently found "iPhone owners were, by far, the least satisfied" with AT\&T. ${ }^{84}$

Given the high market concentration levels and the trend toward concentration in this case, the lower court case law requires that AT\&T and T-Mobile provide "proof of extraordinary efficiencies, which the [merging parties] failed to supply .... . [E]fficiencies almost never justify a merger to monopoly or near-monopoly.” ${ }^{85}$ Moreover, given the high concentration levels and the business ${ }^{86}$ and behavioral economics literature ${ }^{87}$ on the

79. See, e.g., William J. Kolasky, What Is Competition? A Comparison of the U.S. and European Perspectives, 49 AnTiTRust Bull. 29, 35 (2004) (“[C]ompetition is the process by which market forces operate freely to assure that society's scarce resources are employed as efficiently as possible to maximize total economic welfare.”); William J. Kolasky \& Andrew R. Dick, The Merger Guidelines and the Integration of Efficiencies into Antitrust Review of Horizontal Mergers, 71 AnTITRUST L.J. 207, 208 (2003) ("The fundamental reason we favor competition over monopoly is that competition tends to drive markets to a more efficient use of scarce resources.”).

80. AT\&T SUBMISSION, supra note 70, at 24.

81. Id.

82. Consumer Reports cell-service Ratings: AT\&T is the worst carrier, CONSUMER REPORTS (Dec. 6, 2010, 2:08 PM), http://news.consumerreports.org/electronics/2010/12/ consumer-reports-cell-phone-survey-att-worst.html.

83. AT\&T Submission, supra note 70, at 2.

84. Andrew Dowell, Consumer Reports Says AT\&T 'Worst-Rated' U.S. Carrier, WALL ST. J., (Dec. 7, 2010), http://online.wsj.com/article_email/SB100014240527487041 56304576003423395003238-lMyQjAxMTAxMDIwMjEyNDIyWj.html.

85. FTC v. H.J. Heinz Co., 246 F.3d 708, 720 (D.C. Cir. 2001) (relying on the Horizontal Merger Guidelines).

86. DAVIDSON, supra note 8, at 64; Waller, Corporate Governance, supra note 9, at 873-79 (examining evidence from corporate finance that suggests entire categories of 
failure of many mergers to provide any significant value to shareholders or consumers, the courts should, and likely would, "undertake a rigorous analysis of the kinds of efficiencies being urged by the parties in order to ensure that those 'efficiencies' represent more than mere speculation and promises about postmerger behavior." 88

\section{B. AT\&T and T-Mobile Have Not Rebutted the Presumption That the Significant Increase in Concentration in an Already Highly Concentrated Industry Will Increase the Likelihood of Tacit Collusion.}

As the D.C. Circuit said, "[t] he combination of a concentrated market and barriers to entry is a recipe for price coordination." 89 AT\&T and TMobile have not rebutted this presumption. To successfully rebut the ordinary presumption that either tacit or express collusion increases in a highly concentrated industry postmerger, the merging parties would have to establish with credible evidence that "[s]tructural market barriers to collusion" are unique to their industry. ${ }^{90}$ The merging parties have not shown why their industry is so unique that by removing a significant competitor like T-Mobile will not make it easier to collude tacitly postmerger.

Section 7.1 of the Merger Guidelines defines the general conditions necessary for coordinated effects:

Pursuant to the Clayton Act's incipiency standard, the Agencies may challenge mergers that in their judgment pose a real danger of harm through coordinated effects, even without specific evidence showing precisely how the coordination likely would take place. The Agencies are likely to challenge a merger if the following three conditions are all met: (1) the merger would significantly increase concentration and lead to a moderately or highly concentrated market; (2) that market shows signs of vulnerability to coordinated conduct (see Section 7.2); and (3)

mergers are more likely to destroy, rather than enhance, shareholder value); Clayton $\mathrm{M}$. Christensen et al., The Big Idea: The New M\&A Playbook, HARV. Bus. REv., Mar. 2011, at 49 ("study after study puts the failure rate of mergers and acquisitions somewhere between 70\% and 90\%”); Walter Adams \& James W. Brock, Antitrust and Efficiency: A Comment, 62 N.Y.U. L. REV. 1116, 1117 n.8 (1987) (collecting earlier studies).

87. See, e.g., Donald C. Langevoort, The Behavioral Economics of Mergers and Acquisitions, 12 TENN. J. Bus. L. 65, 71-74 (2011), available at http://trace.tennessee. edu/transactions/vol12/iss2/4; Ulrike Malmendier, A "New" Paradigm in Corporate Finance: The Role of Managers and Managerial Biases, 4 NBER REPORTER 13, 15-16 (2010), available at http://www.nber.org/reporter/2010number4/ulrike.html (collecting and discussing earlier field studies that correlate between overconfidence and acquisitions by cash-rich firms not dependent on external financing).

88. H.J. Heinz, 246 F.3d at 721.

89. Id. at 724 .

90. Id. 
the Agencies have a credible basis on which to conclude that the merger may enhance that vulnerability. An acquisition eliminating a maverick firm (see Section 2.1.5) in a market vulnerable to coordinated conduct is likely to cause adverse coordinated effects.

As we discuss in Part III, the industry is already highly concentrated. Moreover, there is no evidence of structural barriers to collusion. The few remaining firms can quickly detect and punish any attempt to increase competition by reducing price. In this industry, pricing and other terms of sale are highly transparent and are easily compared. These terms include: monthly fee; coverage area; included minutes, text, and data; overage and roaming charges; length of contract; penalties; activation fee; and optional features.

The condition that there be rapid responses by rivals also appears to be true. One critic of the acquisition (FreePress) states that AT\&T and Verizon "have a long history of raising prices in concert, as they both did early last year [2010] by requiring all customers on feature phones to add data plans." 92

The FCC gives another example of how transparency affects price competition in its Fourteenth Mobile Wireless Competition Report. The example is particularly noteworthy. It shows how T-Mobile, acting as a price-cutter, prompted AT\&T and Verizon to narrow their price premium on unlimited service offerings:

91. Unlimited Calling Plans. The focus of price competition now appears to be shifting to unlimited service offerings. In an effort to reduce churn, T-Mobile introduced a lower-priced version of its unlimited national voice calling plan in the first quarter of 2009, but limited its availability to select existing customers. With the subsequent launch of its new "Even More" plans in October 2009, TMobile reset prices on tiered offerings at significant discounts to its legacy plans, and brought its pricing structure more closely into line with that of Sprint Nextel, the least expensive nationwide service provider. The biggest pricing changes were made on T-Mobile's unlimited service offerings, which include bundled voice, text and data offerings as well as an unlimited voice-only calling plan. At the same time, T-Mobile discontinued its myFaves unlimited calling circle offer.

92. Even before T-Mobile launched its new pricing plans, Verizon Wireless and AT\&T priced their postpaid service offerings at a premium relative to those of T-Mobile and Sprint Nextel. According to analysts, this premium reflected the willingness of consumers to pay higher prices for access to preferred handsets and data offerings, and in

91. 2010 Horizontal Merger Guidelines, supra note 42, at $\S 7.1$.

92. FreePress, Why the AT\&T-T-Mobile Deal is Bad for America, FreEPress 2 (2011), http://www.freepress.net/files/ATT-TMobile.pdf (footnote omitted). 
Verizon Wireless's case, positive perceptions of its network. TMobile's price changes appear to have prompted Verizon Wireless and AT\&T to narrow the price premium on unlimited service offerings. In January 2010, Verizon Wireless reduced the prices of its unlimited voice plans for both individual and shared family offerings. Later the same day, AT\&T responded to Verizon Wireless's changes with matching price reductions on its unlimited voice plans. While Verizon Wireless's and AT\&T's unlimited plan price cuts were significant, their postpaid service offerings remained the most expensive in the industry, even following these price changes, as the prices of Sprint Nextel's and T-Mobile's equivalent or comparable unlimited plans had already declined sharply.

\section{Comparison of Unlimited Pricing Plans ${ }^{94}$}

\begin{tabular}{|l|c|c|c|c|}
\hline & Verizon Wireless & AT\&T & T-Mobile & Sprint Nextel \\
\hline Voice & $\$ 69.99$ & $\$ 69.99$ & $\$ 59.99$ & Not offered \\
\hline Voice + Text & $\$ 89.99$ & $\$ 89.99$ & $\$ 69.99$ & Not offered \\
\hline Voice + Text + Basic Data & $\$ 99.99$ & $\$ 99.99$ & $\$ 79.99$ & Not offered \\
\hline Voice + Text + Smartphone Data & $\$ 119.99$ & $\$ 119.99$ & $\$ 99.99$ & $\$ 99.99$ \\
\hline
\end{tabular}

There are probably many other examples of competitive moves and responses over time. They may involve the introduction and pricing of calling plans, commitment periods and penalties, pricing for subsidized handsets, and so forth. In each of these dimensions, the market is fully transparent to a competitor.

The merging parties may argue that tacit collusion is unlikely, because, postmerger, Sprint would become the maverick firm and undercut any attempt by AT\&T and Verizon to raise prices, reduce consumer choices, or decrease their incentives to innovate. Sprint's incentives to serve as a maverick would arguably change, however, after a merger. Sprint may conclude that it would do better by going along with AT\&T and Verizon than by trying to undercut them and gain customers. It may be possible to model the gains to Sprint depending on which strategy it pursued.

Nor has AT\&T established that other firms would restore competition postmerger. Other than Sprint and Verizon, the other firms in the market are so small, so capacity constrained, or so dependent on Verizon and AT\&T that they would not be likely to act as a check on coordinated interaction. $^{95}$

93. 14th Mobile Wireless Competition Report, supra note 23, at paras. 91-92 (citations omitted).

94. Id. at para. 92.

95. See 2010 Horizontal Merger Guidelines, supra note 42, § 7.2 (firms with small market shares may serve as a check on coordinated interaction, but only if they can rapidly 


\section{Handset Competition and Innovation}

The merger will also likely lead to less choice and higher prices to consumers for handsets, and will give AT\&T more power over handset suppliers. Price and nonprice competition among the mobile wireless handset manufacturers, according to the FCC, affects competitive outcomes in the mobile wireless service market. Competition is also shaped by the provider-as-retailer model of handset distribution. ${ }^{96}$ "Bundling contracts and exclusive handset arrangements are firm conduct that occurs frequently in the provider-as-retailer model of handset distribution."97

The merger removes a company that buys and subsidizes handsets. The loss of a significant competitor means that handset manufacturers have one less customer they could turn to, or threaten to turn to, in negotiations with mobile service providers. Moreover, consumers may see their choices of handsets narrowed after the merger. Consumer costs for phones could also increase as the merged company faces less competitive pressure to subsidize phone prices as much as before. Another possible effect is that the growth of Android-based devices ${ }^{98}$ will be slowed. T-Mobile has been the leader in offering these devices as a means of countering the iPhone. There are numerous trade press reports and advertisements showing this ongoing competition. ${ }^{99}$

The introduction of Android software and devices is summarized in the FCC's Thirteenth Mobile Wireless Competition Report as follows:

171. The Twelfth Report noted that the development of Android was announced in November 2007 by the Open Handset Alliance-an alliance of 34 handset makers, wireless providers and other technology companies led by Google Inc. (“Google”), T-Mobile, High Tech Computer Corporation ("HTC”), Qualcomm, and Motorola which was formed to accelerate innovation and "openness" in the provision of mobile wireless services. The Twelfth Report further noted that Android was intended to be the "first open, complete, and free platform created specifically for mobile devices,” and that it was set to be commercially deployed in the second half of 2008.

172. As revealed in subsequent reports about its development, the Android system is a set of operating software developed by Google that is designed to support several different objectives. First, Android

expand their sales in the relevant market).

96. 14th Mobile Wireless Competition Report, supra note 23, at para. 311.

97. Id.

98. Google Projects for Android, GOOGLE CODE, http://code.google.com/android/ (last visited Nov. 15, 2011) ("Android is a software stack for mobile devices that includes an operating system, middleware, and key applications.”).

99. See, e.g., Walt Mossberg, Google Answers the iPhone, All Things Digital (Oct. 15, 2008, 9:02 PM), http://ptech.allthingsd.com/20081015/google-answers-the-iphone/. 
supports and brings together in one package a number of applications Google has developed for mobile handsets, including a search service, Google maps and a new advanced mobile Web browser that is intended to rival the browser on the Apple iPhone. Second, Android provides a platform to support a marketplace for applications made by other companies. Like Apple's software development kit and App Store, Android is designed to make it easier for third-party software developers to make their applications available on mobile handsets and to integrate these applications with handset features such as locationsensing technology. Third, despite its use of Google's search service and other Google applications, the Android system allows wireless service providers to customize the Android software to promote their own data services and content. Google is making the Android operating software available free of charge to handset manufacturers [sic] and wireless service providers in order to encourage the development and deployment of handsets based on Android.

173. Although Google originally planned to launch the new Android handsets in the second half of 2008, subsequently the company indicated that the handsets would not be commercially available until the fourth quarter of 2008. Several factors contributed to the delays, including: (1) the inherent difficulty of managing a project in which Google had to collaborate with and coordinate the work of many different providers to support its Android technology platform, including handset manufacturers, wireless service providers, software developers and chip set makers; (2) challenges wireless service providers have encountered in their efforts to customize the Android software and brand their own devices; and (3) various challenges that confronted software developers in working with Google's programming tools and creating programs for Android.

174. Google and T-Mobile unveiled the first Android device, the G1, in September 2008, and the following month T-Mobile became the first U.S. provider to launch a handset that uses the Android operating system. The G1 runs on both T-Mobile's mobile broadband WCDMA/HSDPA network, which T-Mobile is still in the early stages of rolling out, and also on slower networks using older GSM-family technologies. In addition to Google's advanced new mobile Web browser, search interface and other Google applications such as maps, Gmail and YouTube, the G1 also features a touch-screen that slides open to reveal a real physical keypad underneath, a trackball that supplements the touch-screen navigation, GPS navigation, Wi-Fi access and Bluetooth connections, among other gadgets and functions. Although the Google applications come installed on the G1, the G1 has an applications store, called the Android Market, where G1 users will be able to download programs created by third-party developers. However, while Google maintains that the G1 leaves it up to consumers to decide what they want to run on their cellphones, one reviewer points out that the G1 is "tightly tied to Google's Web-based email, contacts and calendar programs.” Nevertheless, while noting many differences between the G1 and Apple's iPhone, the same 
reviewer concludes that, like Apple's product, Google's G1 is "a serious handheld computer with a powerful new operating system.”100

Choice of devices is important to consumers, who increasingly are choosing a wireless service based on the devices that are available. According to the FCC's Fourteenth Mobile Wireless Competition Report:

299. Handsets and devices are becoming increasingly central to the dynamics of the overall wireless market. Recent studies show handsets playing an increasingly important role for consumers as a basis for choosing providers, although these studies differ as to the level of importance of handsets to consumers. For example, a recent report from Consumers Union provides data that suggests that many consumers switched to new wireless service providers in order to obtain a particular handset. Specifically, the report states that during the two-year period of 2008 through 2009, 38 percent of respondents who had switched providers did so because it was the only way to obtain the handset that they wanted. The same report also indicates that 27 percent of all respondents had a specific wireless handset in mind when they went shopping for a new handset. A first quarter 2009 survey by Nielsen Company shows handsets were the seventh most important reason consumers chose their existing wireless provider, although handset choice increased in importance to 6.4 percent from 2.9 percent in the third quarter of 2006. Recent analyst reports also identify access to handsets as an increasing challenge faced by midsized and small providers.

Viewed from a handset manufacturer's perspective, the acquisition removes a significant buyer from the market. This is likely to have a nontrivial impact on handset manufacturers' ability to negotiate. It is possible that the change will also reinforce AT\&T's incentives to compete for exclusive deals, and Verizon will also find this to be the most viable strategy. This could easily result in Sprint not being a fully competitive alternative, putting further pressure on its long-term survival given the trends showing the importance of handset choice.

\section{Text Messages}

Text message prices may be an example of successfully coordinated conduct in the wireless industry. The theory is that with only a few firms offering the service, it is relatively easy for those firms to coordinate on pricing, and there does seem to be some evidence that such coordination

100. Implementation of Section 6002(b) of the Omnibus Budget Reconciliation Act of 1993, Thirteenth Report, 24 F.C.C.R. 6185, para. 171-74 (2009), http://hraunfoss.fcc. gov/edocs_public/attachmatch/DA-09-54A1.pdf (citations omitted) (emphasis added).

101. 14th Mobile Wireless Competition Report, supra note 23, at para. 299 (citations omitted). 
has in fact occurred. According to Senator Herb Kohl, who oversaw Senate hearings in 2009 on text message prices:

As their popularity has grown, so has the price charged on a per message basis. From 2006 to 2008, the price of sending and receiving a text message among the four largest cell phone carriers increased by $100 \%$-from 10 to 20 cents per message. The four companies increased their text messaging prices in two steps-first from 10 to 15 cents, and then from 15 to 20 cents-within weeks or even days of each other. These lockstep price increases occurred despite the fact that the cost to the phone companies to carry text messages is minimal-estimated to be less than a penny per message-and has not increased.

The Seventh Circuit recently affirmed the district court's decision not to dismiss a conspiracy case alleging text messaging price-fixing against the four national carriers. ${ }^{103}$ The Court of Appeals noted, among other things, that the four defendants sold ninety percent of U.S. text messaging services; it would not be difficult for such a small group to agree on prices and to be able to detect "cheating"; prices had been declining; and "all at once the defendants changed their pricing structures, which were heterogeneous and complex, to a uniform pricing structure, and then simultaneously jacked up their prices by a third."

Pricing of text messages may present a natural experiment on coordinated pricing behavior in the industry. The use of text messages rapidly expanded in 2008-2009, and the industry at that point apparently was sufficiently concentrated for coordinated interaction to occur. It is also possible that going from four to three "national" firms will result in even higher text message prices, which would be a merger effect.

\section{Parallel Accommodating Conduct}

The 1997 Merger Guidelines stated that "[s]uccessful coordinated interaction entails reaching terms of coordination that are profitable to the firms involved and an ability to detect and punish deviations that would undermine the coordinated interaction." 105 The text message example above is an illustration of a potentially profitable strategy that includes the ability to detect and punish deviations. But economic theory has recognized for some time that there are forms of coordinated interaction that are

102. Press Release, Senator Herb Kohl, Kohl Examines Causes of Rising Text Message Pricing (June 16, 2009), http:// http://kohl.senate.gov/newsroom/pressrelease.cfm?customel_ dataPageID_1464=2870.

103. In re Text Messaging Antitrust Litig., 630 F.3d 622 (7th Cir. 2010).

104. Id. at 628.

105. U.S. Dep’t of Justice \& FTC, Horizontal Merger Guidelines § 2.1, at 18 (1997). 
profitable but do not involve the requirement (borrowed from classic cartel theory) that the firms involved be able to "detect and punish" cheating. ${ }^{106}$

The revised 2010 Merger Guidelines refine the analysis and bring it into line with economic theory. The new Merger Guidelines identify three kinds of coordinated behavior: (1) "explicit negotiation of a common understanding of how firms will compete or refrain from competing”; (2) "a similar common understanding that is not explicitly negotiated but would be enforced by the detection and punishment of deviations ... "; and (3) "parallel accommodating conduct not pursuant to a prior understanding."107

In discussing parallel accommodating conduct, the revised Merger Guidelines state: "Parallel accommodating conduct includes situations in which each rival's response to competitive moves made by others is individually rational, and not motivated by retaliation or deterrence nor intended to sustain an agreed-upon market outcome, but nevertheless emboldens price increases and weakens competitive incentives to reduce prices or offer customers better terms." ${ }^{08}$ There is no need for the participants to "detect and punish" cheating.

DOJ was concerned about parallel accommodating conduct in its challenges to the Worldcom/Sprint and Alcan/Pechiney mergers. ${ }^{109}$ In language that may prove equally applicable here, DOJ alleged in Alcan: "[a]fter the acquisition, the combined firm and its largest North American rival would share market leadership and a common incentive to pursue strategies that emphasize accommodation and do not risk provocation.,110

\section{Unilateral Effects}

Alternatively, the merger can be analyzed under a unilateral effects theory. In the context of the incipiency standard, the agencies' unilateral effects analysis is better viewed as a complement for cases where market definition is less straightforward. In differentiated product industries, some products can be very close substitutes and compete strongly with each

106. See Serge X. Moresi et al., Gauging Parallel Accommodating Conduct CONCERNS WITH THE CPPI 2 (2011) ("Parallel accommodating conduct . . . has a long history in oligopoly theory, dating back more than seventy years.").

107. 2010 Horizontal Merger Guidelines, supra note 42, § 7, at 24.

108. Id. § 7, at 24-25.

109. Carl Shapiro, Deputy Assistant Attorney General for Economics, U.S. Dep't of Justice, Antitrust Div., Update from the Antitrust Division: Remarks as Prepared for the American Bar Association Section of Antitrust Law Fall Forum (Nov. 18, 2010), http://www.justice.gov/atr/public/speeches/264295.pdf at 28-29.

110. Complaint at para. 22, at 8, United States v. Alcan Inc. (D.D.C. 2003), No. 1:030212, available at http://www.justice.gov/atr/cases/f201300/201303.htm. 
other, while other products are more distant substitutes and compete less strongly. A merger between firms selling differentiated products may diminish competition by enabling the merged firm to profit by unilaterally raising the price of one or both products above the premerger level. So, as one recent example, DOJ can challenge a merger involving "value" shampoo, conditioners, and hairspray. ${ }^{111}$ Whether the market is defined as shampoo generally or value shampoo specifically, the antitrust agency can predict that the prices for one or both of the merging firms' product will increase postmerger. The agency will base its prediction on diversion ratios, the estimated consumer demand at postmerger prices, and the profit margins of the merging parties' hair products. ${ }^{112}$

The problem is that unilateral effects theory has become the opium of merger review. If the agency can predict the likely postmerger price increases for value shampoos, white pan bread, or baby wipes, then the merging parties and courts will demand the FTC and DOJ prove for every merger how prices will increase postmerger, and by what magnitude. It is not surprising then that most merger cases in recent years are challenged under a unilateral effects theory. ${ }^{113}$ However, as one former head of the Antitrust Division observed,

[U]nilateral effects should not be the theory of choice simply by default. If we reach too quickly for unilateral effects theories to the exclusion of meaningful coordinated effects analysis, we might miss important cases that should be brought or craft our relief too narrowly in cases that we actually pursue. ${ }^{11}$

Where market definition and entry barriers are relatively straightforward, it is questionable whether DOJ needs to rely on a unilateral effects theory, the utility of which is where market definition is less straightforward or meaningful (such as whether the market is defined as value shampoos or shampoo generally). Nonetheless, we discuss below how a unilateral effects theory applies here. But we do so with the

111. Complaint at para. 2, at 2, United States v. Unilever N.V. (D.D.C. 2011), No. 1:11-00858, http://www.justice.gov/atr/cases/f270800/270856.pdf.

112. Rachel Brandenburger \& Joseph Matelis, The 2010 U.S. Horizontal Merger Guidelines: A Historical and International Perspective, 25-SUM ANTITRUST 48 (2011), http://www.americanbar.org/content/dam/aba/publishing/antitrust_magazine/Antitrust_253_brandenburger_matelis.authcheckdam.pdf; Carl Shapiro, The 2010 Horizontal Merger Guidelines: From Hedgehog to Fox in Forty Years, 77 ANTITRUST L.J. 49 (2010).

113. Charles A. James, Assistant Attorney General, Antitrust Div., U.S. Dep’t of Justice, Rediscovering Coordinated Effects, Address at the American Bar Association Annual Meeting, Section of Antitrust Law (Aug. 13, 2002), http://www.justice.gov/atr/ public/speeches/200124.pdf at 7-8 (noting "one interesting side-effect of the 1992 Guidelines has been the emergence of unilateral effects as the predominant theory of economic harm pursued in government merger investigations and challenges.”).

114. Id. at 9 . 
important caveat that the incipiency standard controls. The fact that DOJ can show that the merger significantly increases the likelihood of a substantial unilateral price increase simply provides additional evidence of why the merger violates the Clayton Act.

Although the Merger Guidelines outline several types of unilateral effects, the most likely candidate theory here involves pricing of differentiated products:

The concept of unilateral effects is simple to describe: In markets characterized by product differentiation, mergers between close competitors are likely to lead to higher prices absent postmerger repositioning of other products in the market and/or efficiencies. In the usual case, the merging firms sell products (A and B) that consumers perceive to be close competitive substitutes for each other. Other products, while perhaps being functional substitutes on some level, are viewed by the consumers of $\mathrm{A}$ and $\mathrm{B}$ to be substantially differentiated from $\mathrm{A}$ and $\mathrm{B}$ in terms of product attributes, such that changes in the prices of A or B do not lead consumers to choose other products in significant numbers. After A and B come under common control, the price of A could be raised because many of the consumers of A would switch to $B$, the profits of which, instead of being lost by the firm selling A, would now be captured by the merged firm. Other consumers would stay with A and pay [the] higher price .... .

It is the diversion of consumers from $\mathrm{A}$ to $\mathrm{B}$, compared to a diversion to any other products, that permits a postmerger price increase. (Note that the same could be said about increases in the price of B leading to significant diversion to $\mathrm{A}[\mathrm{)}]$. $^{115}$

It is beyond this Article's scope to analyze "upward pricing pressure” or diversion ratios. However, several observations may be offered.

It seems likely that the parties are relatively close substitutes. First, they offer similar plans and services, although, T-Mobile tries to price somewhat lower and also has somewhat lower profit margins. ${ }^{116}$

Second, it is likely that the real market for "low-end" customers is in prepaid plans as opposed to postpaid plans. Prepaid plans are a way to cut costs and avoid the lengthy contracts that come with traditional cell phone plans. Prepaid plans have been growing rapidly (probably because of the recession) but they generate much lower revenue per subscriber than postpaid plans. $^{117}$

115. Charles Biggio, Whole Foods' Impact on Unilateral Effects, GLOBAL COMPETITION POLICY, Sept. 2008, http://www.wsgr.com/PDFSearch/wholefoods0908.pdf.

116. See 14th Mobile Wireless Competition Report, supra note 23, at paras. 214-21 (applying various measures of profitability).

117. 14th Mobile Wireless Competition Report, supra note 23, at para. 163. 
If the DOJ applies an "upward pricing pressure" analysis, the result is likely to confirm the intuition (and fear) of many T-Mobile customers: that AT\&T has an incentive to raise T-Mobile prices postmerger. AT\&T has both a significantly higher market share and significantly higher margins than T-Mobile. If AT\&T raises T-Mobile prices postmerger, it will likely recapture a high enough percentage of defecting T-Mobile customers that the price increase will be profitable. On the other hand, AT\&T probably has much less of an incentive to raise prices on its own customers postmerger.

Indeed, AT\&T's own unilateral effects analysis in past transactions highlights this concern. In its November 2008 FCC filing in connection with the acquisition of Centennial Communications, AT\&T argued that Centennial was not a particularly close substitute because "AT\&T focuses on the other national carriers in its competitive decision making and does not consider Centennial in deciding on pricing and service offerings." ${ }^{\text {"118 }}$ It recognized that the number of competitors and share of the merging firms were relevant. ${ }^{119}$ And it is worth noting that AT\&T's past arguments about the ease of competitive repositioning do not square with its own repeated statements in this merger about the increasing demands consumers are placing on wireless networks. ${ }^{120}$

\section{Exclusionary Effects}

Finally, the merger can be analyzed under an exclusionary effects theory. The theory is that a merger may enable the merged firm to engage in exclusionary conduct after the merger-for example, by denying rivals access to needed inputs, by cutting off their access to customers, or otherwise by raising their costs. ${ }^{121}$ When a merger enhances the ability of a firm to exclude rivals, the result may be harm to competition. The harmful

118. AT\&T, MERger of AT\&T Inc. AND Centennial Communications Corp., Description of Transaction, Public Interest Showing and Related Demonstrations 37 (Nov. 21, 2008), available at https://wireless2.fcc.gov/UlsEntry/attachments/attachment ViewRD.jsp;ATTACHMENTS=1N6VJL5K37mPzN1G7L2XKBP7mC5jC50m96ttqVlHZr 3GL1cyJSgx!-659400886!-849295342?applType=search\&fileKey=843683410\&attachment Key=18355849\&attachmentInd=applAttach.

119. Id. at 36 .

120. AT\&T argued in connection with the Centennial acquisition that "[t]he Commission also has noted that a merger such as this one does not take spectrum away from any competing carriers - that is, no competitor is made worse off by the transaction - and has focused its review on whether competitors would be able to compete effectively at a later point in the deployment of next-generation services.” Id. at 27.

121. Sprint raises these concerns in its complaint challenging the merger. Complaint at paras. 208-16, Sprint Nextel Corp. v. AT\&T, Inc. (2011), No. 1:11-cv-01600, http://www. appliedantitrust.com/08_mergerII/cases_doj/att/sprint/sprint_ddc_complaint9_6_2011.pdf. 
effects of exclusionary practices have been recognized both in case law ${ }^{122}$ and by economists ${ }^{123}$ for many years.

The 2010 Merger Guidelines now explicitly make this theory part of the antitrust review. Section 2.2.3 of the Merger Guidelines expresses skepticism toward most competitor concerns about competitive effects, but contains an exception for exclusionary conduct:

Information from firms that are rivals to the merging parties can help illuminate how the market operates. The interests of rival firms often diverge from the interests of customers, since customers normally lose, but rival firms gain, if the merged entity raises its prices. For that reason, the Agencies do not routinely rely on the overall views of rival firms regarding the competitive effects of the merger. However, rival firms may provide relevant facts, and even their overall views may be instructive, especially in cases where the Agencies are concerned that the merged entity may engage in exclusionary conduct. ${ }^{124}$

This theory of harm is particularly relevant to the AT\&T/T-Mobile merger. The merging parties have asserted that smaller regional and local carriers will replace any competition lost through the merger, and, therefore, will constrain AT\&T from exercising market power postmerger. For this claim to be true, the smaller carriers must be able to develop and grow into a significant competitive force in the marketplace. If the merged firm can make it significantly more expensive for the smaller companies to operate, or otherwise act to block or limit their growth, the parties' claim becomes highly suspect.

Exclusionary theories are put forward in a number of the comments on the merger filed with the FCC. As one example, Cincinnati Bell Wireless ("CBW") is a regional carrier that serves approximately 509,000 subscribers in the greater Cincinnati and Dayton metropolitan areas as well as several counties in Indiana and northern Kentucky. ${ }^{125}$ Like AT\&T and T-Mobile, CBW is a GSM-based carrier (GSM or Global System for Mobile Communications is the most prevalent standard for technologies in cellular networks). Because the parties hold out CBW as one of the regional carriers that would allegedly replace the competition lost by the merger, it is worth noting the difference in their relative sizes. Postmerger,

122. See, e.g., MCI Comm. Corp. v. AT\&T, 708 F.2d 1081, 1131-33 (7th Cir. 1983) (holding AT\&T liable for raising the costs of actual and potential entrants into long distance service by denying them equal access to local telephone network).

123. See, e.g., Thomas G. Krattenmaker \& Steven C. Salop, Analyzing Anticompetitive Exclusion, 56 ANTITRUST L. J. 71, 81-82 (1987).

124. 2010 Horizontal Merger Guidelines, supra note 42, § 2.2.3, at 5-6 (emphasis added).

125. Petition of Cincinnati Bell Wireless LLC to Condition Consent or Deny Applications at 7, Applications of AT\&T Inc. and Deutsche Telekom AG (No. 11-65) (2011), available at http://fjallfoss.fcc.gov/ecfs/document/view?id=7021681268. 
the combined AT\&T and T-Mobile would be approximately 250 times the size of CBW, yet CBW would be the second largest GSM-based carrier in the country.

Regional carriers like CBW must give their customers the ability to roam out of the local region onto the networks of other carriers. Because CBW is GSM-based, the only two current choices for a roaming partner in most markets are AT\&T and T-Mobile, ${ }^{127}$ and the company currently has roaming contracts with both of them.

CBW states that AT\&T's rates for voice and data roaming are approximately twice as high as T-Mobile's rates. ${ }^{128}$ Postmerger, AT\&T would be the only remaining $3 \mathrm{G}$ roaming alternative since AT\&T has already announced its intention to shut down T-Mobile's 3G network. ${ }^{129}$ And CBW claims that in the past, AT\&T has engaged in repeated acts of exclusionary conduct, including:

charging unreasonable roaming rates; denying roaming access on its advanced data networks and opening access only after severe delays, at unreasonably high rates, and upon anticompetitive conditions; preventing access to contiguous or quality spectrum by buying it up through both auctions and merger; and denying access to new and innovative handset technology by tying manufacturers into exclusive arrangements and specifying "single carrier" handset designs developed for use only on its network.

It does not require much imagination to see how the proposed merger could make things appreciably worse for firms like CBW and consumers. Losing T-Mobile as a supplier both exposes CBW to a roaming rate increase and increases its vulnerability to further exclusionary conduct by AT\&T. Far from being able to grow and provide meaningful competition to the merged firm, CBW and similar firms are likely to be hemmed in if not further marginalized.

As a final point, the agencies most often encounter exclusionary conduct in vertical mergers or in mergers with a vertical dimension, such as where the merged firm supplies needed inputs to customers who are also competitors. ${ }^{131}$ But there can be exclusionary effects on a purely horizontal

126. Id. at $15-16$.

127. Id. at 3.

128. Id. at 16 .

129. Id. at 6 .

130. Id. at ii (emphasis omitted).

131. Jonathan B. Baker, Comcast/NBCU: The FCC Provides a Roadmap for Vertical Merger Analysis, 25-SPG ANTITRUST 36, 37 (2011) (noting how vertical mergers can harm competition by facilitating exclusion by foreclosing "unaffiliated downstream rivals from access to the integrated firm's upstream product (input foreclosure), and foreclosure of unaffiliated upstream rivals from access to the integrated firm's downstream business 
basis as well. The Merger Guidelines provide an example of such exclusionary effects in an industry characterized by "network effects." Broadly speaking, there are "network effects" if one person's adoption of a good (a) benefits other adopters of the good and (b) increases others' incentives to adopt it. ${ }^{132}$

Merging Firms A and B operate in a market in which network effects are significant, implying that any firm's product is significantly more valuable if it commands a large market share or if it is interconnected with others that in aggregate command such a share. Prior to the merger, they and their rivals voluntarily interconnect with one another. The merger would create an entity with a large enough share that a strategy of ending voluntary interconnection would have a dangerous probability of creating monopoly power in this market. The interests of rivals and of consumers would be broadly aligned in preventing such a merger.

Telecommunications is an industry subject to significant network effects. Indeed, the telephone is a classic example of network effects. In the early, unregulated era of telephone service, the dominant Bell system simply refused to interconnect with independent local phone companies. ${ }^{134}$

The existence of network effects in the mobile wireless industry may be seen in handset exclusivity. As the FCC noted, exclusive contracting for handsets only takes place "with providers that have larger customer bases and extensive network penetration." ${ }^{135}$ Indeed, the FCC notes that while all of the four nationwide providers have some exclusive arrangements, the non-nationwide providers typically do not. ${ }^{136}$

In what ways could the merger change the strategy of the merging parties given the existence of network effects? One possibility is that the merger will further enhance AT\&T's incentive and ability to demand handset exclusivity. A second possibility is that AT\&T, which currently has reciprocal roaming agreements with several carriers, ${ }^{137}$ could find itself

(customer foreclosure)").

132. Joseph Farrell \& Paul Klemperer, Coordination and Lock-In: Competition with Switching Costs and Network Effects, in 3 HANDBOOK OF INDUS. ORG. 1967 (Mark Armstrong and Robert Porter eds., 2007).

133. 2010 Horizontal Merger Guidelines, supra note 42, § 2.2.3, at 6.

134. Wu, supra note 22, at 45-50.

135. Implementation of Section 6002(b) of the Omnibus Budget Reconciliation Act of 1993, Fifteenth Report, 25 F.C.C.R. 11407, para. 342 (2011). WT Docket No. 10-133, http://hraunfoss.fcc.gov/edocs_public/attachmatch/FCC-11-103A1.pdf.

136. Id.

137. See Joint Opposition of AT\&T Inc., Deutsche Telekom Ag, and T-Mobile USA, Inc. to Petitions to Deny and Reply to Comments at 156-58, Applications of AT\&T Inc. and Deutsche Telekom AG (No. 11-65) (2011), http://fjallfoss.fcc.gov/ecfs/document/view? id=7021686831. 
in a position after the merger where it no longer needs those carriers as roaming partners. Reciprocal roaming agreements, according to AT\&T, provide a check on roaming rates since the parties need each other. ${ }^{138}$ Postmerger, the situation may be more like AT\&T and CBW, where CBW roams on AT\&T's network but not vice versa. ${ }^{139}$

A third possibility involves network infrastructure. T-Mobile was a founding member of the "Open Handset Alliance," a broad alliance of technology and wireless firms that joined forces to develop the Android platform. ${ }^{140}$ Such an alliance requires the possibility of a return on considerable investments. One can readily imagine a postmerger world in which the inability to reach a sufficient number of wireless customers would make it impossible for a firm or group of firms to recoup their investments, and, as a result, the investments would not be made.

\section{REMEDIES}

As Part III shows, this merger is presumptively anticompetitive. As Part IV discusses, AT\&T and T-Mobile in their public documents have not overcome this presumption of illegality by (i) showing how consumers will overall benefit with merger-specific efficiencies and (ii) rebutting the presumption that the significant increase in concentration, in an already highly-concentrated industry, will increase the likelihood of tacit collusion. Consequently, looming large is the question of remedy. At the end of the day, if DOJ concludes that the merger violates the Clayton Act, what is the cure? There are three possibilities: sue to block the merger, agree to divestitures, or agree to behavioral conditions.

In the past several years, wireless mergers involving the four national facilities-based providers have mostly involved an expansion of coverage, and the entities that were combined for the most part had not competed in most of the geographic areas. Where there was overlap, the FCC required divestitures. A chart of the recent mergers appears below. ${ }^{141}$

138. Reply of Cincinnati Bell Wireless LLC at 5, Applications for Consent to the Transfer of Control of Licenses at 5, Applications of AT\&T Inc. and Deutsche Telekom AG (No. 11-65) (2011), available at http://fjallfoss.fcc.gov/ecfs/document/view?id= 7021688585.

139. Id.

140. Press Release, Industry Leaders Announce Open Platform for Mobile Devices (Nov. 5, 2007), available at http://www.openhandsetalliance.com/press_110507.html.

141. 14th Mobile Wireless Competition Report, supra note 23, at para. 75, Table 9. 


\begin{tabular}{|c|l|}
\hline $\begin{array}{c}\text { Year of } \\
\text { Commission } \\
\text { Approval }\end{array}$ & \multicolumn{1}{|c|}{ Merger } \\
\hline 2005 & Sprint/Nextel \\
\hline 2007 & AT\&T/Dobson \\
\hline 2008 & $\begin{array}{l}\text { AT\&T/Aloha } \\
\text { T-Mobile/Suncom } \\
\text { Verizon Wireless/Rural Cellular } \\
\text { Verizon Wireless/Alltel } \\
\text { Sprint Nextel/Clearwire }\end{array}$ \\
\hline 2009 & AT\&T/Centennial \\
\hline
\end{tabular}

Significantly, according to the FCC, most of the divestitures in the Verizon/Rural Cellular and Verizon/Alltel mergers were to go to AT\&T. Most of the divestitures in the AT\&T/Centennial merger were to go to Verizon. ${ }^{142}$ Assuming this took place, it shows how few potential buyers there were, and that the FCC and DOJ were apparently willing to accept an increase in national market concentration to remedy local concerns. The question is whether the same analysis would apply here when the present acquisition (i) would increase concentration nationally and in numerous local markets, and (ii) is not a geographic expansion. At a minimum, it is highly unlikely that either the FCC or DOJ would accept divestitures to Verizon in the present merger. In addition, DOJ prefers to have a single buyer on the theory that a merger that removes a single competitor is best remedied by replacing the single competitor with another as opposed to a group. ${ }^{143}$ But divesting assets to someone who is already in the market does not really remedy the competitive loss caused by a merger. ${ }^{144}$

142. Id. at para. 84

143. Indeed, the DOJ guidelines on merger remedies refer to a single purchaser of the assets. U.S. Dep’t of Justice, Antitrust Div., Antitrust Division Policy Guide to MERGER REMEDIES (June 2011), http://www.justice.gov/atr/public/guidelines/272350.pdf [hereinafter 2011 Policy Guide to Merger Remedies].

144. DOJ noted that its approval will be conditioned on three fundamental tests, one of which is that the "divestiture of the assets to the proposed purchaser must not itself cause competitive harm":

For example, if the concern is that the merger will enhance an already dominant firm's ability unilaterally to exercise market power, divestiture to another large competitor in the market is not likely to be acceptable, although divestiture to a fringe incumbent might. If the concern is one of coordinated effects among a small set of postmerger competitors, divestiture to any firm in that set would itself raise competitive issues. In that situation, the Division 


\section{A. Behavioral Remedies}

Behavioral conditions or behavioral remedies include imposing the requirement that the merged company agree to price or access terms, or otherwise change its conduct. For example, if there is concern that AT\&T could disadvantage its competitors by charging excessive special access fees, AT\&T could be ordered to provide access on reasonable and nondiscriminatory terms. If there is concern about exclusive agreements with handset manufacturers, AT\&T could agree not to enter such exclusive agreements.

DOJ, under the Obama Administration, has been receptive to behavioral remedies, whereby DOJ permits a merger but regulates the behavior of the merging parties. ${ }^{145}$ Historically, based on sound practical reasons, the antitrust agencies preferred structural remedies (requiring divestiture of assets) over behavioral ones.

Behavioral remedies are unattractive for many reasons, as DOJ itself has recognized. ${ }^{146}$ DOJ is not set up as a regulatory agency. The staff that works on this merger will be disbanded and move on to other matters when the review is finished. The head of DOJ Antitrust Division from both Republican and Democratic parties have said that DOJ is not, and should not be, in the business of ongoing oversight of remedies. Indeed, to the extent that DOJ is market-oriented, behavioral remedies are perverse, in that they limit the ability of a firm to make market-based decisions, and they are by necessity applied only to the merged firm and not to its competitors.

Thus, behavioral remedies should be used only when no other alternative exists, such as in vertical mergers where the main theory of harm is that rivals will be foreclosed from the market. ${ }^{147}$ In telecommunications mergers, they tend to be used mostly for the sake of parallel orders. ${ }^{148}$ If the FCC wants to impose a behavioral remedy, DOJ may also include it in a decree. But it should be understood that adding

\footnotetext{
likely would approve divestiture only to a firm outside that set. Id. at 28.

145. Id. at $12-13$.

146. U.S. DeP't of Justice, Antitrust Division Policy Guide to Merger Remedies 8-9 (Oct. 2004, rev. 2011), http://www.justice.gov/atr/public/guidelines/205108.htm.

147. 2011 Policy Guide to Merger Remedies, supra note 143, at 2 (“[C]onduct remedies often can effectively address anticompetitive issues raised by vertical mergers.").

148. See, e.g., Philip J. Weiser, Reexamining the Legacy of Dual Regulation: Reforming Dual Merger Review by the DOJ and the FCC, 61 FED. COMM. L.J. 167, 179 (2008) " "When the DOJ imposes a behavioral requirement to address concerns about vertical relations, it often replicates or anticipates efforts taken by the FCC.”). The author goes on to give several examples.
} 
behavioral remedies to a consent decree usually accomplishes little, if anything, from DOJ's standpoint-it is done because it is a relatively lowcost, even if relatively low-return, proposition.

\section{B. Divestitures}

Partial divestiture of assets by one or both of the merging firms is a different story. Divestitures may be ordered if only parts of a deal are problematic. In a horizontal merger, divestitures are used to fix competitively significant overlaps. ${ }^{149}$ If the acquiring company offers many products, but only competes with the acquired company in one of those products, that product line may be divested. Or if the acquiring company competes with the acquired company in only one geographic location, its business in that location may be divested. So the first point is that divestitures generally only make sense when the problematic overlaps are small relative to the size of the deal.

A second issue is, who is the buyer? Divestitures, like any remedy, are intended to replace the competition lost through a merger. This has led to a number of requirements being imposed on a prospective buyer before DOJ will approve the buyer. For example, you do not want a buyer who has never managed a business like the one being divested. Firms who enter new and unfamiliar businesses often fail. ${ }^{150}$ For similar reasons, you do not want a buyer who is undercapitalized and needs to rely on the merged company to provide financing. That buyer may pull its punches because it is on the hook to the merged company. You also do not want the divested assets sold to several smaller buyers. While each of those buyers may be fine, they are also individually weaker than the original firm was, and, therefore, may be less effective competitors. Finally, you want an entire business divested, not just pieces of the business. History teaches that divestitures of complete businesses are much more likely to succeed than just certain assets or licenses. ${ }^{151}$

So let us apply these well-accepted principles to the current AT\&T/TMobile merger. First, the overlaps here are not small relative to the size of

149. 2011 Policy Guide to Merger Remedies, supra note 143, at 5 ("Divestiture of overlapping assets, usually an existing business entity, can effectively preserve competition that the merger otherwise would eliminate.”).

150. Staff of the Bureau of Competition of the Federal Trade Commission, A Study of the Commission's Divestiture Process 23 (1999) (“mistakes by buyers are inherent in the acquisition process, particularly where buyers have no previous experience in the market.”).

151. 2011 Policy Guide to Merger Remedies, supra note 143, at 8 ("The Federal Trade Commission Divestiture Study found that divestitures of on-going businesses succeeded at a higher rate than divestitures of selected assets.”) (footnote omitted). 
the deal. This is not a geographic expansion merger involving a handful of competitive overlaps, as was the case with prior wireless mergers. ${ }^{152}$ As previously stated, the relevant geographic market in this case appears national. But even on a local market basis, there are likely to be hundreds of local markets where AT\&T and T-Mobile compete for customers, and where both are among the top four competitors. If DOJ finds likely competitive effects in all or most of those local markets, divestiture becomes an unattractive remedy.

Second is the question of the identity of the buyer. The goal is to have a buyer (or buyers) that will restore the competition lost by the disappearance of T-Mobile. A large buyer like Sprint would be one option, but only in those markets where it does not have a sizeable presence already. Otherwise, even with a divestiture, the number of players is being reduced postmerger.

A small buyer may be unattractive, since it may be unable to deliver what T-Mobile did for its customers. For example, a small carrier may depend more on its larger rivals than T-Mobile does. And that could end up meaning it has a higher cost structure, or is dependent on its competitors, in ways that T-Mobile is not.

Third is the question of what assets are being divested. The answer has to be primarily licenses for spectrum. And here we run into another problem. If, AT\&T asserts it needs T-Mobile's spectrum, what are the merging parties going to divest? Spectrum. But since spectrum is the driver of the deal, it does not make sense that AT\&T will simply sell off TMobile's spectrum everywhere that there is overlap. Rather, the likely result would be "mix and match" divestitures. ${ }^{153}$ AT\&T will be willing to divest the spectrum that it does not need, but keep the spectrum that it needs or is more desirable. We have seen something similar happen in radio mergers, where the merged company keeps the bigger stations and agrees to divest the smaller ones. AT\&T's antitrust counsel would likely offer the same deal. Of course, it may happen by chance that a buyer needs precisely the same spectrum that AT\&T is willing to divest, but that is

152. The four current nationwide facilities-based mobile telephone providers largely built their nationwide footprints through various mergers and acquisitions. A number of the more recent acquisitions are described in the FCC's Thirteenth Mobile Wireless Competition Report. Implementation of Section 6002(b) of the Omnibus Budget Reconciliation Act of 1993, Thirteenth Report, 24 F.C.C.R. 6185, paras. 52-62, (WTB 2009), http://hraunfoss.fcc.gov/edocs_public/attachmatch/DA-09-54A1.pdf.

153. A "mix and match" divestiture is one that includes some of the acquiring firm's assets and some of the acquired firm's assets. See, e.g., Frequently Asked Questions about Merger Consent Order Provisions, FEDERAL TRADE COMMISSION, http://www.ftc.gov/bc/ mergerfaq.shtm (last visited Nov. 15, 2011). 
unlikely to happen. A profit-maximizing firm does not pay thirty-nine billion dollars in order to sell competitors the best spectrum.

So what is the argument in favor of divestitures? In the larger or urban geographic markets in which the merging parties compete, AT\&T will likely argue that it need not divest anything. Those are the local markets where its needs are most acute. It will undoubtedly argue that these are also the markets that have the most provider choices, and also that T-Mobile is not much of a competitive factor, especially in the 4G future.

In the smaller or rural overlap markets, where there is less choice, AT\&T probably would be willing to divest. Indeed, its likely endgame is to limit its divestitures just to those markets. Why? That solves a couple of the problems mentioned above. First, it means that the divestitures become a much smaller part of the overall deal. Second, it means that buyers can probably be found and approved. Third, the buyer will likely not pose a significant competitive threat to AT\&T nationwide postmerger.

During the DOJ investigation, the merging parties' endgame most likely was to keep the DOJ focused on narrowly-defined geographic markets, progressively attempting to whittle down the number of geographic markets where DOJ had concerns. By compartmentalizing the merger into small regions, AT\&T and T-Mobile could hope to horse trade with DOJ on the divesture of assets in smaller markets like Knoxville, Tennessee. There is nothing sinister with this strategy; indeed, it happens regularly at the agencies. While we were at DOJ in the 1990s-2000s, we saw this piecemeal approach for radio $^{154}$ and bank mergers. ${ }^{155}$ In retrospect, it is questionable whether these piecemeal divestitures in consent decrees actually restored the competition lost by the mergers and prevented the risks from the trend toward consolidation.

Now that DOJ and the states have filed suit, AT\&T and T-Mobile are likely to follow a similar strategy in any settlement offer they make. However, this strategy is made more difficult by the fact that a complaint has been filed. Any settlement must remedy the competitive harms alleged in the complaint. Because the complaint has alleged harm to numerous local markets (including some very large local markets) as well as national effects from the merger, a small number of localized divestitures would be inadequate to remedy the alleged harm to competition.

154. See Maurice E. Stucke \& Allen P. Grunes, Why More Antitrust Immunity for the Media is a Bad Idea, 105 Nw. U. L. Rev. Colloquy 115, 128-30 (2010) (citing Joel I. Klein, Acting Assistant Att'y Gen., Dept. of Just., Speech at the ANA Hotel: DOJ Analysis of Radio Mergers (Feb. 1997)), available at http://ssrn.com/abstract=1710466.

155. See Maurice E. Stucke, Lessons from the Financial Crisis, 77 ANTITRUST L.J. 313 (2010). 


\section{Enjoining the Merger}

This brings us to the last remedy: blocking the merger. Actually, according to the Supreme Court, that is the first remedy courts are supposed to consider. On the question of remedies, United States v. E. I. Du Pont De Nemours \& Co., which is still good law, states:

The very words of $\S 7$ suggest that an undoing of the acquisition is a natural remedy. Divestiture or dissolution has traditionally been the remedy for Sherman Act violations whose heart is intercorporate combination and control, and it is reasonable to think immediately of the same remedy when $\S 7$ of the Clayton Act, which particularizes the Sherman Act standard of illegality, is involved. Of the very few litigated $\S 7$ cases which have been reported, most decreed divestiture as a matter of course. Divestiture has been called the most important of antitrust remedies. It is simple, relatively easy to administer, and sure. It should always be in the forefront of a court's mind when a violation of $\S 7$ has been found. 156

Given the unattractiveness of behavioral remedies and the likely inadequacy of piecemeal divestitures, the preferred remedy seems clear.

\section{CONCLUSION}

The AT\&T/T-Mobile merger is presumptively anticompetitive under Philadelphia National Bank. There are important policy reasons for this legal presumption, including providing greater certainty to consumers and the industry participants, increasing transparency and accountability of the antitrust agencies, and reducing the risk of political capture of the agencies. ${ }^{159}$ Here on a national level, this is a four to three merger in a highly concentrated industry. The industry, through past mergers, has accelerated toward greater concentration. The industry has high entry barriers. There is no indication that the market shares overstate competitive significance.

The merging parties must provide convincing evidence to overcome the presumption. To date, they have not. AT\&T and T-Mobile have not established why the market is not susceptible to coordinated effects. There is also reason to believe that AT\&T could unilaterally raise prices to TMobile's customers postmerger. At the end of the day, the proposed merger likely violates Section 7 of the Clayton Act and should be enjoined.

156. United States v. E. I. Du Pont De Nemours \& Co., 366 U.S. 316, 329-31 (footnotes omitted). Note that DuPont uses the word "divestiture" to mean complete divestiture (i.e., preventing an acquisition), not divestiture of some assets.

157. These policy reasons are elaborated in Maurice E. Stucke, Does the Rule of Reason Violate the Rule of Law?, 42 U.C. DAVIS L. REV. 1375 (2009). 
